\title{
Molecular Pathways Involved in the Development of Congenital Erythrocytosis
}

\author{
Jana Tomc and Nataša Debeljak *(D) \\ Medical Centre for Molecular Biology, Institute of Biochemistry and Molecular Genetics, Faculty of Medicine, \\ University of Ljubljana, SI-1000 Ljubljana, Slovenia; jana.tomc@mf.uni-lj.si \\ * Correspondence: natasa.debeljak@mf.uni-lj.si; Tel.: +386-1-543-76-45
}

Citation: Tomc, J.; Debeljak, N. Molecular Pathways Involved in the Development of Congenital Erythrocytosis. Genes 2021, 12, 1150 https://doi.org/10.3390/genes12081150

Academic Editor: Mariarosa Anna Beatrice Melone

Received: 16 June 2021

Accepted: 26 July 2021

Published: 28 July 2021

Publisher's Note: MDPI stays neutral with regard to jurisdictional claims in published maps and institutional affiliations.

Copyright: (c) 2021 by the authors. Licensee MDPI, Basel, Switzerland. This article is an open access article distributed under the terms and conditions of the Creative Commons Attribution (CC BY) license (https:// creativecommons.org/licenses/by/ $4.0 /)$.

\begin{abstract}
Patients with idiopathic erythrocytosis are directed to targeted genetic testing including nine genes involved in oxygen sensing pathway in kidneys, erythropoietin signal transduction in pre-erythrocytes and hemoglobin-oxygen affinity regulation in mature erythrocytes. However, in more than $60 \%$ of cases the genetic cause remains undiagnosed, suggesting that other genes and mechanisms must be involved in the disease development. This review aims to explore additional molecular mechanisms in recognized erythrocytosis pathways and propose new pathways associated with this rare hematological disorder. For this purpose, a comprehensive review of the literature was performed and different in silico tools were used. We identified genes involved in several mechanisms and molecular pathways, including mRNA transcriptional regulation, post-translational modifications, membrane transport, regulation of signal transduction, glucose metabolism and iron homeostasis, which have the potential to influence the main erythrocytosis-associated pathways. We provide valuable theoretical information for deeper insight into possible mechanisms of disease development. This information can be also helpful to improve the current diagnostic solutions for patients with idiopathic erythrocytosis.
\end{abstract}

Keywords: congenital; familial; erythrocytosis; disease mechanisms; signal transduction; transcriptomic; proteomic; metabolomics

\section{Introduction}

Oxygen homeostasis involves several tissues and organs, including the heart, lungs, bone marrow and blood. Any imbalance in its homeostatic mechanisms can result in hematological disorders, such as anaemia or erythrocytosis. Most often erythrocytosis is the compensatory mechanism of heart or lung disease (secondary acquired erythrocytosis). Rarely erythrocytosis is a consequence of single gene variant (monogenic disorder), that can be acquired (JAK2, indicative for polycythaemia vera, PV) or inherited (EPOR, VHL, EGLN1, EPAS1, EPO, HBB, HBA, BPGM, indicative for congenital erythrocytosis, ECYT) [1,2]. The genetic disorder can also be caused by the combined action of more than one gene (digenic or polygenic disorder). However, this mechanism is not well addressed in the case of erythrocytosis. An update on the currently known causes of inherited erythrocytosis can be reviewed in publication within this issue by M.F. McMullin (2021) [3].

After excluding the mutation in $J A K 2$, patients with persistent erythrocytosis from a young age or with a family history are usually screened for mutations in 9 genes involved in oxygen sensing in kidneys (EPOR, VHL, EGLN1, EPAS1,EPO), erythropoietin signal transduction in pre-erythrocytes $(E P O R)$ and hemoglobin-oxygen affinity regulation in mature erythrocytes (HBB, HBA, BPGM). However, in more than $60 \%$ the genetic cause remains undiagnosed, suggesting that other genes and mechanisms must be involved in the disease development. Understanding the main regulatory pathways in the process of oxygen homeostasis is necessary to identify new potential factors, which have not been yet associated with erythrocytosis but could contribute to its development. Besides, this can 
further improve the diagnostic methods for prompt and accurate diagnosis and selection of appropriate treatment.

In this paper, we aim to review molecular mechanisms correlated with known oxygen sensing HIF-EPO pathway, EPO-EPOR signal transduction pathway, and hemoglobinoxygen $\left(\mathrm{Hb}-\mathrm{O}_{2}\right)$ affinity modulation. Furthermore, additional new mechanisms that could be implicated in the development of erythrocytosis are investigated, including regulation of erythropoiesis, metabolism, and hormone homeostasis. Comprehensive research of the literature was performed and different in silico tools were used, including Reactome [4], String [5], UniProt [6], GeneCards [7], Human Protein Atlas [8], NCBI [9], and HGNC [10] databases. We carefully revised the mechanisms involved in regulation of RNA transcription, as the expression level of key players can extensively moderate described pathways. Furthermore, regulation at the protein level was studied in details, identifying mechanisms that affect protein-protein interactions, protein modifications, and membrane transport. Regulation of signal transduction is important for all extracellular signals, as signaling pathways can be attenuated or enhanced. Non the less, the revision of metabolism is necessary, as modulation of glucose and iron metabolism was confirmed to be involved in the development of erythrocytosis [11,12].

\section{Known Molecular Pathways Involved in Congenital Erythrocytosis}

\subsection{Oxygen-Sensing: HIF-EPO Pathway}

Often named also the HIF-EPO pathway after its key molecules, this signaling cascade has a prominent role in oxygen sensing by hypoxia-inducible factors (HIF). In tissue hypoxia, the transcription factor HIF- $\alpha$ will dimerize with HIF- $\beta$ and bind to hypoxiaresponse elements (HRE) on promotor of several tissue-specific proteins, including erythropoietin (EPO). Accumulation of HIF2 $\alpha$, the main HIF- $\alpha$ subunit in kidneys, will result in EPO synthesis and increased erythrocyte production in the bone marrow. In normoxia, HIF2 $\alpha$ is degraded by prolyl hydroxylase (PHD2) and von Hippel-Lindau (VHL) protein, while in hypoxia PHD2 is not active resulting in HIF2 $\alpha$ accumulation.

Any imbalance in molecular mechanisms of HIF-EPO pathway can result in hematological disorders. Four types of erythrocytosis are known to be caused by mutations in genes encoding key players of oxygen-sensing signaling, namely VHL (ECYT2), EGLN1/PHD2 (ECYT3), EPAS1/HIF2 $\alpha$ (ECYT4) and EPO (ECYT5) [13]. These mutations mainly result in HIF $2 \alpha$ accumulation in normoxia, due to loss of VHL and PHD2 function (impaired degradation) or gain of HIF $2 \alpha$ function (increased stability). The role of EPAS1 paralogues (HIF- $\alpha$ subunits HIF1 $\alpha$ and HIF3 $\alpha$ ), ARNT (HIF- $\beta$ subunit HIF1 $\beta$ ) and EGLN1 paralogues (EGLN2/PHD1 and EGLN3/PHD3) in development of erythrocytosis has also been studied, but it has not been confirmed. Targeted exome NGS analysis of patients with idiopathic erythrocytosis by Camps et al. (2016) [14], including known disease-causing oxygen-sensing genes (EPAS1, EGLN1,VHL) and novel candidate genes from oxygensensing pathway (EPO, HIF1A, HIF3A, HIF1AN, EGLN2, EGLN3, BHLHE41, OS9, ZNF197, $K D M 6 A$ ) confirmed variants in all known disease-causing genes and identified five novel candidate genes associated with ECYT. The novel gene variants found within this study were located in EPO, EPAS1 paralogue HIF3A, EGLN1 paralogue EGLN2, and two factors associated with HIF; OS9 Endoplasmic Reticulum Lectin (OS9) and class E basic helix-loophelix protein 41 (BHLHE41 or SHARP1) [14]. Furthermore, the role of DNA non-coding regions in development of erythrocytosis should further be considered, as it has already been confirmed in EPO and VHL by functional studies [15,16].

During our in silico research, we identified new candidate genes involved in transcriptional activation or repression, post-translational modifications, and nuclear transport. These mechanisms can directly or indirectly modulate the stability or activity of key transcription factor HIF $2 \alpha$ and affect the process of EPO production (for a recent review see [17]). However, as HIF $2 \alpha$ also plays a role in cancer development and progression and the greater number of available information is cancer-directed, their enrolment in the regulatory mechanisms in healthy tissue must be considered with caution. The key 
players of the oxygen-sensing pathway are presented in Figure 1. Regulation of EPAS1 is extensively revised as an integrative regulatory map within this special issue.

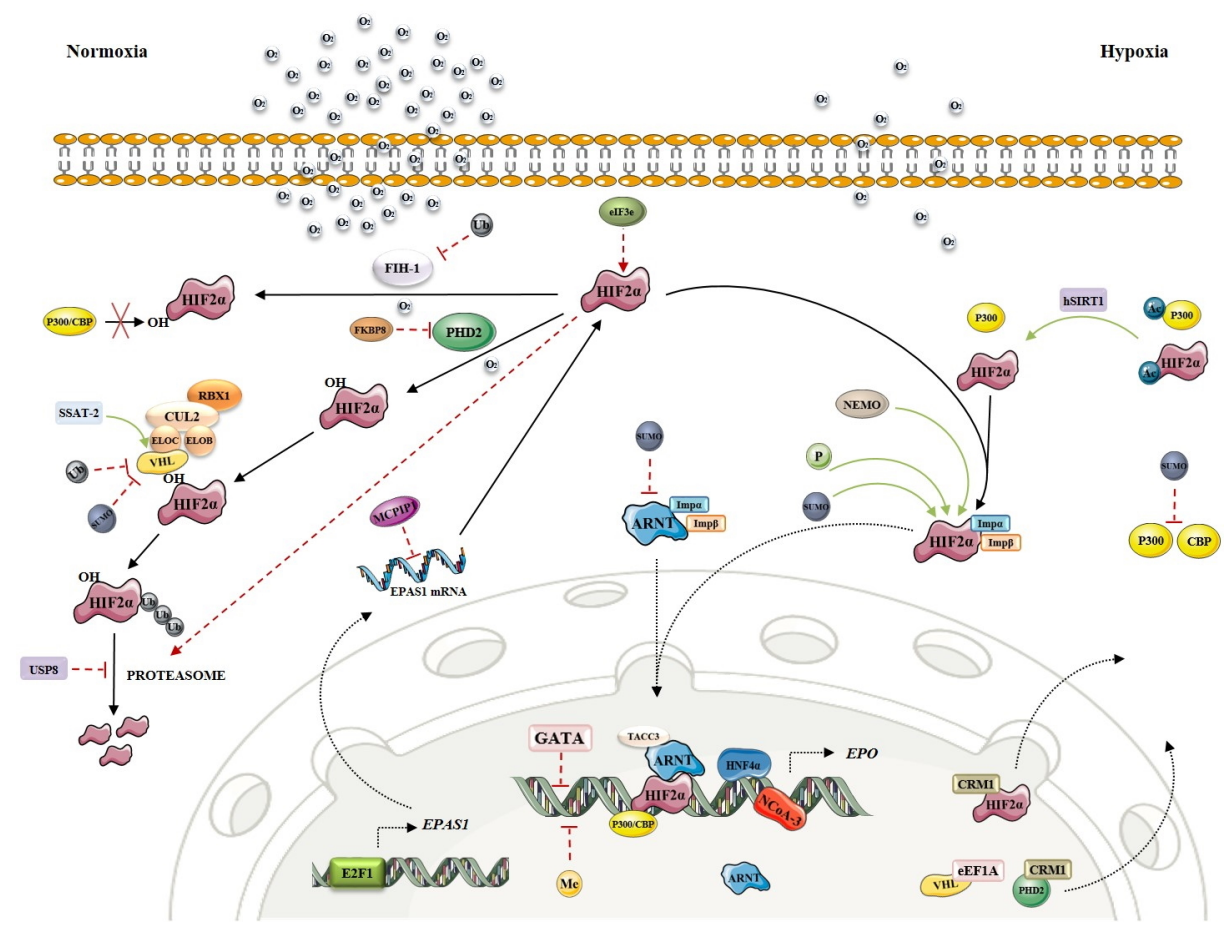

Figure 1. Molecular mechanisms of HIF-EPO pathway. The red line indicates an inhibitory effect. Green line indicates the activation/stabilization effect. Black line indicates transition. Circles denote post-translational mechanisms: P-Phosphorylation, Ac-Acetylation, Me-Methylation, SUMOSumoylation, $\mathrm{Ub}$-Ubiquitynation (Figure was created using SMART servier medical art [18]).

\subsubsection{Regulation at the RNA Level}

Oxygen sensing depends on the tight regulation of all key players, including $V H L$, EGLN1, EPAS1 and ARNT.

The HIF1 $\beta$ subunit (encoded by gene ARNT) is constitutively expressed in all tissues, while the expression of three HIF $\alpha$ subunits is tissue specific. There is not much information available about the regulation of HIF2 $\alpha$ (encoded by gene EPAS1) expression in the kidney and liver. Depending on the cell line used, HIF2 $\alpha$ mRNA is regulated by transcription factor E2F1, deubiquitylase Cezanne, transcription factors SP1 and SP3 and others [19,20]. Apart from that, MCP-induced protein 1 and DNA methyltransferases (DNMTs) have been reported to negatively regulate the transcription of EPAS1 gene [21,22]. HIF also regulated the RNA expression of transferrin (TF) and transferrin receptor (TFR), the key players in iron metabolism (see Section 3.2).

PHD2 (encoded by gene EGLN1) promoter contains an HRE region and its transcription is positively regulated by $\operatorname{HIF} 1 \alpha[23,24]$. Besides, transforming growth factor $\beta-1$ (TGF $\beta 1$ ) has been demonstrated to negatively regulate PHD2 expression through SMAD signaling in HepG2 cells [25].

The analysis of specific transcription factor binding sites within the VHL promoter identified a significant positive regulatory element as an SP1 binding site [26]. Furthermore, FOXO3a has been recently reported to play a role in hypoxia signaling by direct binding to the VHL promoter and upregulation of VHL expression [27]. HIF1 $\alpha$-dependent upregulation of $V H L$ expression as a negative feedback loop during hypoxia has also been suggested [28].

$E P O$ gene expression is regulated by HIF2 $\alpha-\mathrm{HIF} 1 \beta$ complex and p300/CBP transcriptional co-activators in cooperation with other transcription factors, such as hepatocyte nuclear factor- $4 \alpha(\mathrm{HNF} 4 \alpha)$ [29], retinoid X receptor $\alpha(\mathrm{RXR} \alpha)$ [30], or nuclear receptor 
coactivator 3 (NCoA-3) [31]. Transcription factors GATA2 and GATA3 have been shown as negative regulators of $E P O$ transcription [32,33]. Besides, methylation of $\mathrm{CpGs}$ in the promoter or $5^{\prime}$-untranslated regions represses $E P O$ transcription by blocking the binding of sequence-specific DNA binding proteins or recruitment of methyl-CpG binding protein 2 [34]. An extensive study of one family with idiopathic erythrocytosis indicated, that transcription of $E P O$ mRNA from an alternative promoter, due to the frameshift mutation in exon 2 that interrupts translation of the main $E P O$ mRNA, can lead to excess production of erythropoietin and erythrocytosis [15]. EPO expression may be induced by several metals (cobalt, nickel and manganese) and by iron chelation (see Section 3.3).

\subsubsection{Regulation at the Protein Level}

Protein Interactions and Modifications

$\mathrm{HIF} \alpha$ proteins can be directly or indirectly modulated by post-translational modifications. Beside to $\mathrm{O}_{2}$ dependent hydroxylation, also phosphorylation [35-37], acetylation [38,39], methylation [40], ubiquitination [41] and sumoylation [42,43] have been found to affect its transcriptional activity or stability. However, many of these post-translational mechanisms do not require $\mathrm{O}_{2}$ as a co-factor.

Apart from post-translational modifications, other protein interactions can regulate the activity of HIFs. Several modulators of HIF $2 \alpha$ are known, such as NF-kappa-B essential modulator (NEMO) and class E basic helix-loop-helix protein 41 (bHLHe41) [44,45]. Likewise, many proteins interact with PHD2 and VHL and consequently regulate HIF2 $\alpha$ hydroxylation or ubiquitination and HIF2 $\alpha$ stability [46-51]. VHL is the substrate recognition component of Cullin Ring Ubiquitin ligase complex (CRL), consisting of elongins $B$ and C (ELOB and ELOC), scaffold protein cullin-2, and ubiquitin-protein ligase RBX1, and all these components play an important role in VHL-dependent ubiquitination and degradation of HIF2 $\alpha$ [52]. Besides, transforming acidic coiled-coil-containing protein 3 (TACC3) can act as a co-activator of the HIF complex by interacting with constitutively expressed HIF1 $\beta$ subunit [53].

\section{Nuclear Transport}

Intracellular transport of the oxygen-sensing machinery represents an important level of control of transcriptional activity of HIF subunits in oxygen homeostasis. Unlike HIF $2 \alpha$, which shuttles between nucleus and cytoplasm, HIF1 $\beta$ is permanently inside the nucleus [54]. Importins $\alpha 1, \alpha 3, \alpha 5$ and $\alpha 7$ bind to both HIF $2 \alpha$ and HIF1 $\beta$, allowing their translocation into the nucleus. HIF $2 \alpha$ can also associate directly with importin $\beta$ which mediates the interaction with the nuclear pore complex [55]. Nuclear export of HIF $\alpha$ subunits is regulated by exportin 1 (CRM1), and HIF2 $\alpha$ has been sown to associate with CRM1 in a phosphorylation-sensitive manner regulated by MAP1/3 kinases [56]. Transport between nucleus and cytoplasm has been reported also for PHD2 and VHL, wherein nuclear export of the two proteins involves CRM1 [54] or elongation factor 1- $\alpha 1$ (EEF1A1) [57].

\subsection{Signal Transduction: EPO-EPOR Pathway}

EPO stimulates proliferation, survival and differentiation of erythroid progenitors in the bone marrow by binding to EPO receptors (EPOR) expressed on their surface. Tyrosine phosphorylation plays a pivotal role in EPOR signal transduction and the activation of downstream signaling cascades involved in erythropoiesis, including the signal transducer and activator of transcription 5 (STAT5), phosphatidylinositol 3-kinase (PI3K) and mitogenactivated protein kinase (MAPK/ERK) pathways [58-60]. The key players of EPO-EPOR signal transduction have been recently reviewed and are presented in Figure 2 [61,62]. 


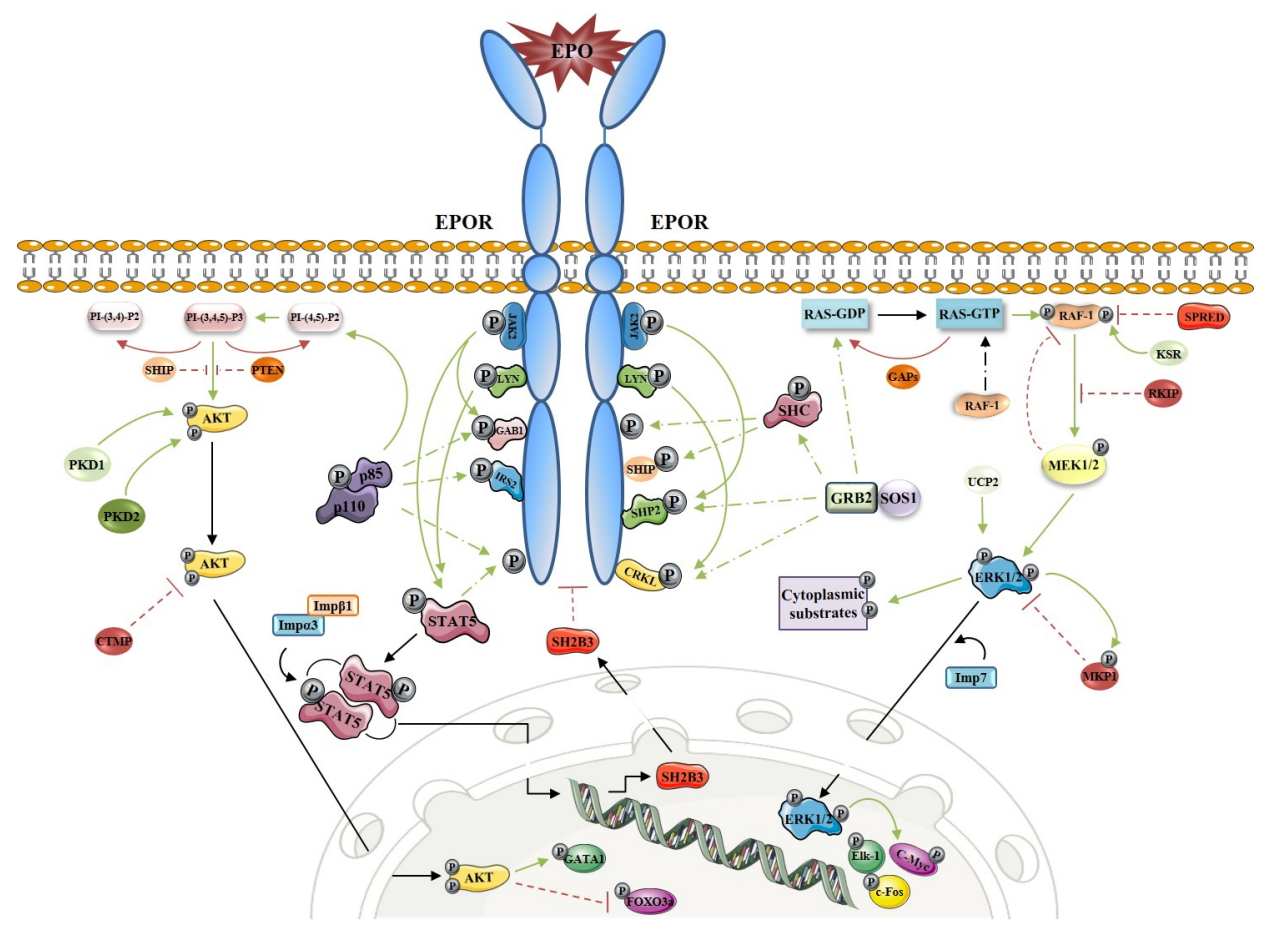

Figure 2. Molecular mechanisms of EPO-EPOR signal transduction pathways: STAT5 pathway, PI3K pathway and MAPK pathway. Red line indicates an inhibitory effect. Green line indicates the activation effect. Black line indicates transition (Figure was created using SMART servier medical art [18]. Figure adapted from [61,62]).

Abnormally increased or prolonged activation of the three pathways is implicated in deregulated erythropoiesis and overproduction of red blood cells in polycythemia vera and congenital erythrocytosis [59], wherein inherited mutations in the EPOR itself (ECYT1), and acquired mutations in JAK2 (PV) are already well known genetic causes [1,63]. All mutations result in prolonged EPOR signal transduction, due to a gain of JAK2 and EPOR function. The JAK2 mutation results in the impaired auto-inhibitory domain, and consequently prolonged JAK2 autophosphorylation and STAT5 pathway activation, while some EPOR mutations result in the loss of EPOR negative regulatory mechanisms, such as loss of SHP1 binding site, and consequently prolonged JAK2 autophosphorylation and STAT5 pathway activation [64]. Occasionally, mutations in gene encoding SH2B adapter protein 3 (LNK; SH2B3) may account for or at least contribute to the erythrocytosis phenotype, and it has already been suggested that $\mathrm{SH} 2 \mathrm{~B} 3$ mutations should be a part of the investigation of idiopathic erythrocytosis $[65,66]$. Furthermore, severe erythrocytosis has been observed in SOCS3 null mice [67]. Targeted exome NGS analysis of patients with idiopathic erythrocytosis by Camps et al. (2016) included three known disease-causing genes involved in EPOR signal transduction (EPOR, SH2B3, JAK2) and confirmed their role in the development of erythrocytosis [14]. Rare $J A K 2$ germline mutations have been associated with the hereditary type of erythrocytosis [68]. Several somatic mutations in the genes JAK2, TET2, NFE2, KMT2A and/or TP53 have been found in cases of polycythemia vera [69].

During our in silico research we identified new candidate genes encoding adaptor proteins, tyrosine kinases and phosphatases that participate in phosphorylation and activation, and especially in negative regulation of EPOR and the regulation of STAT5, PI3K and MAPK signaling cascades. Besides, genes involved in nuclear transport and regulation of EPOR mRNA expression should not be neglected. The contribution of these mechanisms to abnormal signal transduction and deregulated erythropoiesis should be further investigated. Mathematical modeling may facilitate future research, as a similar model of the JAK2/STAT5 signaling pathway, used in cancer research, can be applied also for modeling erythrocytosis [70]. 


\subsubsection{Regulation at the RNA Level}

Erythroid transcription factor GATA1 plays a central role in erythroid development, and its binding motifs have been identified in EPOR promoter/enhancer. Signaling through EPOR can increase the expression and activation of GATA1 which in turn upregulates EPOR mRNA expression in late CFU-E/proerythroblast progenitors [64]. However, the mRNA expression of EPOR is tightly regulated by GATA1 in coordination with transcription factors SP1 and TAL1, which both stimulate the transcription [71-73]. Especially SP1 has been shown as a critical element in transcriptional activation of the EPOR promoter [72].

Transcriptional regulation of key downstream players of EPOR signaling cascade shall also be revised, including JAK2, STAT5, PI3K, and MAPK. Furthermore, the interplay between epigenetics and transcriptional regulation must be further addressed [74,75].

\subsubsection{Regulation at the Protein Level}

Protein Interactions and Modifications in STAT5 Pathway

STAT5 refers to two proteins, which share $94 \%$ structural homology and are transcribed from STAT5A and STAT5B genes [76]. Both proteins are predominant signal transducers for EPOR and essential in regulating erythroid differentiation and survival [76,77].

Activation of this pathway involves STAT5 recruitment to the phosphorylated EPOR and tyrosine phosphorylation by JAK2, dissociation from the receptor, and formation of homodimers [78]. STAT5 dimers are recognized by importins $\alpha 3$ and $\beta$, allowing them to translocate into the nucleus [79]. Together with other transcription factors, such as TAL1, GATA1, and KLF1, STAT5 dimers associate with promoter and enhancer regions of target genes to upregulate their expression [75]. Recently, more than 300 STAT5-occupied sites in response to EPO have been identified, including many new genes involved in driving erythroid cell differentiation [80].

Besides JAK2, several members of the Src family tyrosine kinases have been reported to phosphorylate tyrosine residues of STAT5, such as proto-oncogene tyrosine-protein kinase SRC [81], tyrosine-protein kinase FYN [78], and tyrosine-protein kinase LYN [58]. LYN is also involved in the tyrosine phosphorylation of EPOR itself, as well as activates other signaling molecules [82]. Another signaling molecule that associates with and modulates STAT5 activity in response to EPO is CRK-like adapter protein (CRKL) [83]. Furthermore, 22 new EPO-modified kinases and phosphatases have been recognized in a study by Held et al. (2020) [84], including protein tyrosine phosphatase non-receptor type 18 (PTPN18), which is highly expressed in hematopoietic progenitors. PTPN18 has been shown not only to promote STAT5 signal transduction for EPO-dependent hematopoietic cell growth, but also signal transduction of PI3K and MAPK pathways [84].

\section{STAT5 Negative Regulation}

STAT5 activity is inhibited through inhibitory mechanisms of protein-tyrosine phosphatase SHP1, SH2B adapter protein 2 (SH2B2) and 3 (SH2B3). SH2B3 (synonym LNK), for example, blocks the STAT5 pathway by inhibiting EPOR phosphorylation and JAK2 activation [78,85], and recruitment of SHP1 to a segment of the EPOR causes dephosphorylation of JAK2 and down-regulation of EPOR signals [86,87]. Suppressors of cytokine signaling (SOCS) 1, 2 and 3, and cytokine-inducible SH2-containing protein (CISH) have been shown as the most potent inhibitors of EPO signaling [67]. CISH associates with activated EPOR and recruits a complex of elongin $B$, elongin $C$, cullin5 and RBX2, to provide E3 ubiquitin ligase activity towards nearby substrates, including STAT5, leading to their degradation [80]. SOCS3 is especially essential to control the STAT5 phosphorylation levels. Apart from functioning in a similar way to CISH, SOCS3 also binds directly to JAK2 as well as to the activated EPOR and inhibits EPO-dependent cell proliferation and STAT5 activation [67]. SOCS3 activity might be inhibited in the absence of SOCS2, as SOCS2 knock-down in MDS cell lines resulted in hyper-phosphorylation of STAT5 [88]. Furthermore, serine/threonine-protein kinase pim-1 (PIM1) has been reported to interact with and potentiate inhibitory effects of SOCS1 and SOCS3 on STAT5 [89]. Genes encoding PIM1, 
$\mathrm{CISH}$, and SOCS3 have been identified as STAT5 target genes. Another gene regulated by STAT5 and involved in negative regulation of EPOR signaling is clathrin interactor 1 (CLINT1), which contributes to receptor internalization [80].

Protein Interactions and Modifications in PI3K Pathway

PI3 kinase signaling plays an important role in EPO-induced proliferation and differentiation of erythroid progenitors, protecting the cells from apoptosis and regulating EPO-induced mitogenic responses. The central mediator of the PI3K pathway is serine/threonine kinase AKT (protein kinase B; PKB) [90], which regulates the activity or expression of important transcription factors and genes [91,92].

Phosphorylation of PI3K after EPO stimulation can be induced by binding of PI3K regulatory subunit (p85) to phosphorylated EPOR, or through mechanisms that involve GRB2-associated-binding proteins (GAB) 1 and 2 or insulin receptor substrate-2 (IRS2). All three mechanisms are equally active in primary erythroid progenitors [91,93]. Activated PI3 kinase further phosphorylates phosphatidylinositol 4,5-bisphosphate (PI-(4,5)-P2) to produce phosphatidylinositol 3,4,5-trisphosphate (PI-(3,4,5)-P3) which is an AKT activator. It recruits AKT to the cell membrane, causing AKT conformational alterations, and activates 3'phosphoinositide-dependent protein kinase 1 (PDK1) which phosphorylates AKT. AKT is double-phosphorylated by PKD2, separated from the membrane and translocated to the nucleus rapidly and transiently, where it further mediates its enzymatic effects [90,94].

\section{PI3K/AKT Negative Regulation}

The activity of AKT and its downstream signaling is negatively regulated by several phosphatases, such as phosphatase and tensin homologue (PTEN), and phosphatidylinositol3,4,5-trisphosphate 5-phosphatases (SHIP) 1 and 2. While PTEN transforms the AKT activator PI-(3,4,5)-P3 into PI-(4,5)-P2, SHIPs dephosphorylate PI-(3,4,5)-P3 to PI-(3,4)-P2. The expression of SHIP1 is largely restricted to hematopoietic cells, while SHIP2 appears to be more widely expressed $[90,95]$. Another component of negative regulation of the AKT signaling is carboxyl-terminal modulator protein C (CTMP). CTMP has been shown to directly interact with AKT at the plasma membrane and to inhibit its phosphorylation [96].

Up to now, the performance of PI3K/AKT in the process of erythropoiesis has not been studied as much as other signaling pathways, and future research in this area could be beneficial for a better understanding of its regulatory mechanisms and contribution to the development of erythrocytosis.

\section{Protein Interactions and Modifications in MAPK Pathway}

One of the key pathways involved in erythropoiesis is the RAS/RAF/MAPK signal transduction cascade. Balanced activation of this pathway is important for promoting proliferation and anti-apoptosis of erythroid progenitors, and its downregulation has been indicated as critical for final erythroid maturation [97].

The pathway is activated by tyrosine phosphorylation of SHC-transforming protein 1 (SHC) that forms a complex with growth factor receptor-bound protein 2 (GRB2) and son of sevenless homolog 1 (SOS1) [87,98]. Besides, GRB2 can bind to tyrosine-phosphorylated CRKL protein, which is in hematopoietic cells recruited to phosphorylated EPOR after EPO stimulation and becomes tyrosine-phosphorylated by LYN [99]. EPO also induces tyrosine phosphorylation of SHIP, which has been shown to associate with EPOR and to form a ternary complex with SHC and GRB2, resulting in activation of MAPK pathway [100]. In EPO-treated UT-7 cells, tyrosine-phosphorylated IRS2 has been demonstrated to associate with SHIP [83]. Phosphatase SHP2 has also been reported to initiate the MAPK signaling pathway after EPO stimulation by recruitment to EPOR and GRB2 [101].

After interacting with GRB2, SOS1 is recruited to the plasma membrane where it activates GTPase RAS by stimulating the exchange of GDP for GTP. GTP-RAS recruits proto-oncogene serine/threonine-protein kinase RAF (RAF-1) to the cell membrane, thus enabling activation of RAF kinase [102,103]. Three human RAS proteins function as 
regulated GDP/GTP molecular switches, H-, K-, and N-RAS respectively, and they can all activate RAF-1 [104]. Active RAF-1 further phosphorylates and activates the dual specificity mitogen-activated protein kinase kinases (MEK) 1 and 2, and MEK1/2 phosphorylates the tyrosine and threonine residues of their only known physiological substrates mitogen-activated protein kinases (MAPK or ERK) 1 and 2 [105]. Activated ERK1/2 kinases phosphorylate a large number of substrates localized in the cytoplasm and nucleus, and for the latter, nuclear translocation of ERK $1 / 2$ is required and occurs through its interaction with importin $7[87,104,106]$.

Other signaling molecules can additionally modulate individual components of the MAPK cascade. UCP2 protein, for example, can interact with ERK1/2 and regulate its phosphorylation in the process of erythropoiesis [107]. Also, RAF-1 activation can be increased through interaction with several kinases and other proteins, such as SRC kinase, protein kinase C (PKC) family members, serine/threonine-protein kinase (PAK) 3, JAK2 or kinase suppressor of RAS (KSR) [104,108]. Furthermore, malignant fibrous histiocytomaamplified sequences with leucine-rich tandem repeats 1 (MASL1), a candidate oncogene, have been shown to interact with RAF-1 and activate erythroid differentiation [109].

\section{MAPK Negative Regulation}

ERK1/2 kinases are dephosphorylated and inactivated by serine/threonine or tyrosine phosphatases and dual-specificity MAP kinase phosphatases (MKPs), such as PP2A, PP2C, STEP, HePTP, PTP-SL, MKP-1, PAC1, hVH3, MKP-3, MKP-X [110]. MKPs activity, however, is also positively regulated by ERK1/2 kinases [94]. Recently, 6 novel phosphatases have been found to be implicated in the inhibition of the MAPK pathway, although their roles in erythropoiesis need further exploration [97]. RAS activity is negatively regulated through GTPase activating proteins (GAPs), such as RASA1, SynGAP or Neurofibromin, that promote the formation of inactive GDP-bound RAS [111]. EPO-induced MEK mediated hyper-phosphorylation of RAF-1 has been shown to result in inhibition of RAF-1 kinase activity towards MEK [98], and RAF kinase inhibitor protein (RKIP) has been demonstrated to disrupt the interaction between RAF-1 and MEK kinases, consequently inhibiting the phosphorylation and activation of MEK [112]. Spred proteins have been reported as general inhibitors of the MAPK signaling pathway, by binding to RAS and RAF-1 and suppressing the phosphorylation and activation of RAF-1 [113]. Importantly, Spred1 and Spred2 are induced by EPO in primary bone marrow-derived CFUe-like progenitors [114].

\subsection{Hemoglobin-Oxygen Affinity Modulation}

Hemoglobin $(\mathrm{Hb})$ in mature erythrocytes is mainly responsible for the transport of $\mathrm{O}_{2}$ from the lungs to the tissues and $\mathrm{CO}_{2}$ from the tissues to the lungs. $98 \%$ of $\mathrm{O}_{2}$ in the bloodstream is in a Hb-bound state. To accommodate maximum space for $\mathrm{Hb}$, erythrocytes lack the nucleus and most of the cytoplasmic organelles. This also allows the drastic modification of their biconcave shape, enabling the passage through microcapillaries and providing an optimal area for respiratory exchange $[1,115]$. The key players of hemoglobin oxygen affinity are presented in Figure 3.

Increased oxygen affinity of $\mathrm{Hb}$ causes impaired delivery of $\mathrm{O}_{2}$ to tissues, resulting in hypoxia, induced EPO production and therefore secondary erythrocytosis. Up to now, two types of erythrocytosis have been associated with mutations in hemoglobin genes, HBA1, HBA2 (ECYT7) and HBB (ECYT6) respectively, however hemoglobin variants do have diverse pathophysiology $[1,116]$. Most of the $\mathrm{Hb}$ variants arise from amino acid substitutions that alter the $\alpha 1 \beta 2$ interface, the $C$ - terminal end of the $\beta$ chain or the 2,3BPG binding site, which stabilize $\mathrm{R}$ state $\mathrm{Hb}$ or inhibit the affinity of $\mathrm{Hb}$ for its allosteric regulators that stimulate $\mathrm{O}_{2}$ release [117]. Very rare BPGM variants resulting in 2,3-BPG depletion and increased oxygen affinity of $\mathrm{Hb}$ have been described to cause ECYT8 [1]. A mild erythrocytosis has been reported also as a consequence of mutations in gene encoding cytochrome b5 reductase (B5R) enzyme [3,118], defects in PKLR gene, encoding glycolytic pyruvate kinase [11,119], and deficiency in the phosphofructokinase (PFK) enzyme [120]. 
Targeted exome NGS analysis of patients with idiopathic erythrocytosis by Camps et al. (2016) included four known disease-causing genes involved in $\mathrm{Hb}-\mathrm{O}_{2}$ modulation (BPGM, $H B A 1, H B A 2, H B B)$ and confirmed their role in the development of erythrocytosis [14]. Analysis of PKLR was included in the recent study by Kristan et al. (2021) as its role in the development of erythrocytosis has been previously indicated [11,121].

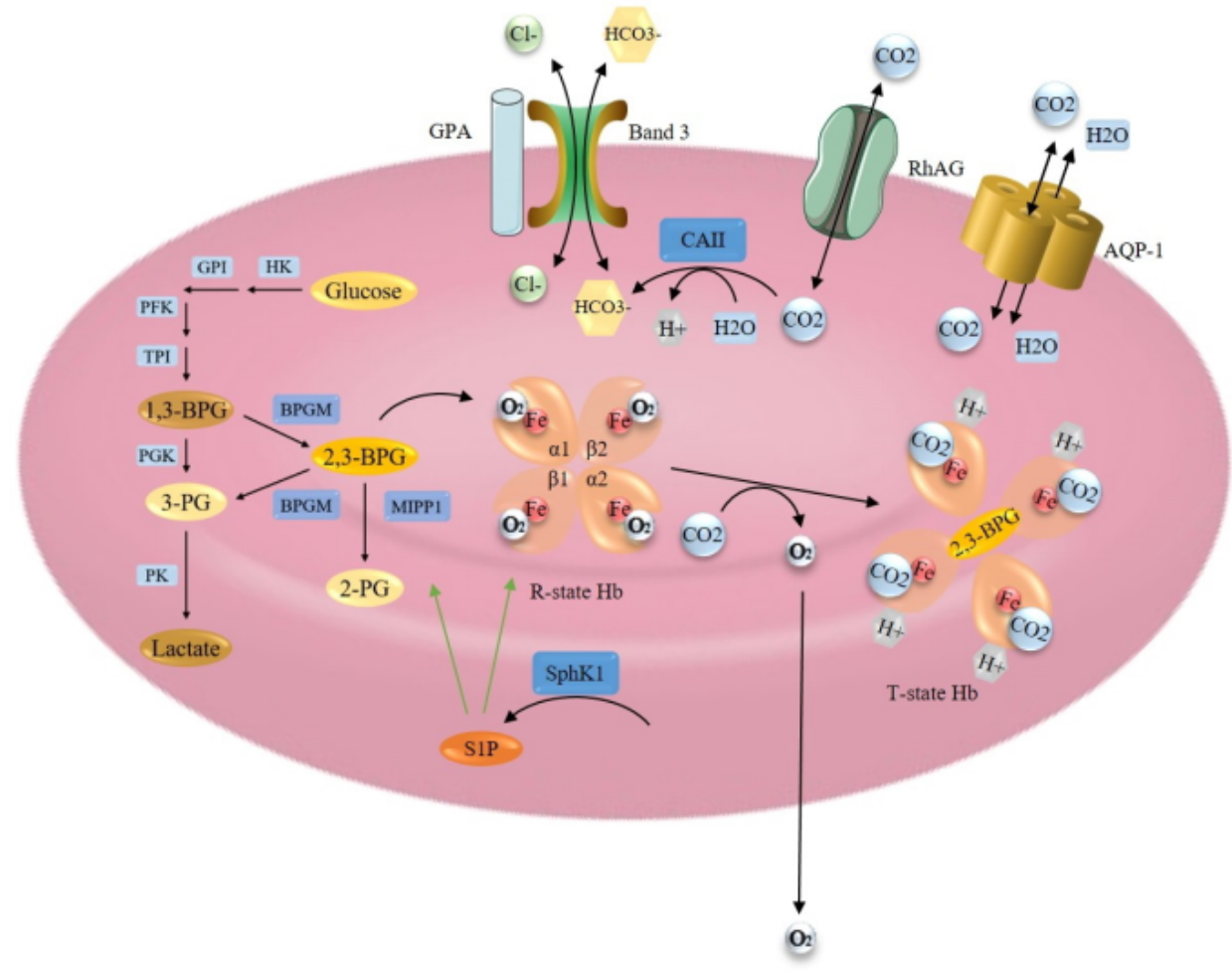

Figure 3. Erythrocyte and hemoglobin structure and function modulation, gas transport and glycolysis pathway, including Rapoport-Luebering shunt. Green line indicates the activation effect. Black line indicates transition (Figure was created using Reactome database [4]).

During our in silico research, we identified new candidate genes encoding hemoglobin modulators, membrane proteins and enzymes involved in glucose metabolism. Genes involved in the regulation of $\mathrm{Hb}$ mRNA expression were also investigated.

\subsubsection{Regulation at the RNA Level}

GATA1 is a crucial regulator of not only genes encoding hemoglobin subunits, but also heme biosynthetic enzymes [122]. Transcription regulation of main hemoglobin genes $H B B, H B A 1, H B A 2$, and enzyme BPGM shall be revised further in detail.

\subsubsection{Regulation at the Protein Level}

Hemoglobin Structure and Function Modulation

Erythrocytes of normal adults contain mainly adult hemoglobin $(\mathrm{HbA}), 2.5-3.5 \%$ $\mathrm{HbA} 2$, and $<1 \%$ fetal hemoglobin $(\mathrm{HbF}) . \mathrm{HbA}$ is a heterotetramer composed of $\alpha$ and $\beta$ globin subunits, each bound to a heme prosthetic group, iron (II) protoporphyrin IX [123]. Individual globin subunit forms a dimer with the unlike globin chain through two distinct interfaces, high-affinity $\alpha 1 \beta 1$ and low-affinity $\alpha 1 \beta 2$ [117]. Heme is a critical component of $\mathrm{Hb}$ which reversibly binds $\mathrm{O}_{2}$ through reduced state iron $\left(\mathrm{Fe}^{2+}\right)$, located within a hydrophobic pocket on the external surface of the protein [124]. Oxidized $\left(\mathrm{Fe}^{3+}\right)$ heme cannot bind $\mathrm{O}_{2}$ and is relatively unstable. It is reduced to functional $\left(\mathrm{Fe}^{2+}\right)$ heme by the B5R enzyme [125]. $\alpha$ globin subunit is encoded by HBA2 and HBA1 paralogous genes [126], and the $H B B$ gene encodes the $\beta$ globin subunit. $\mathrm{HbA} 2$, consisting of two $\alpha$ and two $\delta$ globin subunits, has an unknown physiological role. However, the HBD gene that encodes 
the $\delta$ globin subunit, is a member of the $H B B$ gene cluster [127]. HbF, consisting of two $\alpha$ and two $\gamma$ globin subunits (genes HBG1 and HBG2), is the dominant form expressed during fetal development with high oxygen affinity. $\mathrm{HbF}$ starts to decline just before birth and is gradually replaced by $\mathrm{HbA}$ over several months after birth. This switch is mediated by a replacement of $H B G$ with $H B B$ gene expression in definitive erythroid progenitors [128,129]. No erythrocytosis-causing variants of subunit coding genes $H B D$ and $H B G$ are known.

Oxygenation causes a change in the shape of globin chains. $\alpha 1 \beta 2$ interaction is destabilized by oxygen binding, resulting in a transition of the structure from the deoxygenated (T) state to the oxygenated (R) state, which facilitates the uptake of $\mathrm{O}_{2}$ by other subunits $[117,130]$. The $\mathrm{O}_{2}$ affinity properties of $\mathrm{Hb}$ are fine-tuned by several allosteric regulators, such as protons $\left(\mathrm{H}^{+}\right), \mathrm{CO}_{2}, 2,3$-diphosphoglycerate (2,3-BPG) and chloride ions $\left(\mathrm{Cl}^{-}\right)$, which all promote the release of $\mathrm{O}_{2}$ [131]. $\mathrm{CO}_{2}$, taken up by erythrocytes, is metabolized by carbonic anhydrase enzyme (CA1) and, predominantly, by carbonic anhydrase II (CA2) to bicarbonate $\left(\mathrm{HCO}_{3}{ }^{-}\right)$and $\mathrm{H}^{+}$. $\mathrm{CO}_{2}$ combines with the $\mathrm{N}$-terminal $\alpha$-amino groups of $\mathrm{HbA}$, while $\mathrm{H}^{+}$binds histidine residues in $\mathrm{HbA}$. This results in a conformational change of $\mathrm{Hb}$, promoting $\mathrm{O}_{2}$ release. Besides, the efflux of $\mathrm{HCO}_{3}{ }^{-}$from erythrocyte acidifies the cell and causes the release of oxygen from $\mathrm{Hb}$. In the lungs these reactions are reversed, relatively low $\mathrm{CO}_{2}$ and thus high $\mathrm{pH}$ facilitates $\mathrm{O}_{2}$ binding to $\mathrm{Hb}$ [117,131]. 2,3-BPG is generated during glycolysis and its level is controlled by the bisphosphoglycerate mutase (BPGM) enzyme. 2,3- BPG binds in a central cavity of the $\mathrm{Hb}$ tetramer. Its binding converts the $\mathrm{Hb}$ to a low oxygen affinity state, allowing the efficient off-loading of $\mathrm{O}_{2}[1,117,130,132]$.

\section{Gas Transport}

Two membrane proteins are responsible for extremely high $\mathrm{CO}_{2}$ permeability of erythrocyte membrane, the water channel aquaporin-1 (AQP-1) and the Rhesus blood group type A glycoprotein (RhAG), both acting as $\mathrm{CO}_{2}$ channels [133]. Band 3 or anion exchanger 1 , however, is the predominant glycoprotein of the erythrocyte membrane, responsible for $\mathrm{HCO}_{3}{ }^{-} / \mathrm{Cl}^{-}$exchange, which is carried out by its membrane-spanning domain. This protein also constitutes a short C-terminal cytoplasmic domain, which binds CA2 enzyme, and a large $\mathrm{N}$-terminal cytoplasmic domain, which binds glycolytic enzymes, $\mathrm{Hb}$ and hemichromes. Through its terminal domains, band 3 can maintain in close contact $\mathrm{Hb}$ and $\mathrm{CA} 2$ [131]. It has also been reported that the binding of deoxy- $\mathrm{Hb}$ to the cytoplasmic domain of band 3 causes the release of glycolytic enzymes from membrane to the cytosol to enhance glycolysis and 2,3-BPG production [134]. Besides, band 3 and Rh proteins have been demonstrated to form a band 3 macrocomplex [131]. Band 3 supposed to interact also with Glycophorin A (GPA), and it has been suggested that GPA promotes the cell surface expression and correct folding of band 3 for its proper function [135].

\subsubsection{Regulation at the Metabolic Level: Glycolysis and Oxygen Affinity Regulators}

Erythrocytes during maturation loose nuclei, ribosomes and mitochondria, therefore they are completely dependent on glycolysis. Energy is generated via the anaerobic conversion of glucose to pyruvate or lactate by the Embden-Meyerhof pathway. The pathway is regulated by several glycolytic enzymes, including hexokinase (HK), glucose-6-phosphate isomerase (GPI), phosphofructokinase (PFK), aldolase, triosephosphate isomerase (TPI), glyceraldehyde-3-phosphate dehydrogenase (G-3-PD), phosphoglycerate kinase (PGK), pyruvate kinase (PK) and others [115]. Inside the Embden-Meyerhof pathway, erythrocytes possess a unique glycolytic bypass, the Rapoport-Luebbering shunt that avoids the PGK step of 1,3-diphosphoglycerate (1,3-BPG) conversion to 3-phosphoglycerate (3-PG). Instead, the bypass accounts for the synthesis and regulation of 2,3-BPG, the major glycolytic intermediate in erythrocytes, and its levels are about equal to the sum of the other glycolytic intermediates. The erythrocyte-specific BPGM is well known for catalyzing the formation of 2,3-BPG from 1,3-BPG and hydrolysis of 2,3-BPG to 3-PG, which then reenters the main glycolytic pathway $[115,136]$. Importantly, Cho et al. (2008) [136] identified a second enzyme component of the Rapoport-Luebbering shunt with 2,3-BPG phosphatase activity, 
multiple inositol polyphosphate phosphatase (MIPP1). Unlike BPGM, MIPP1 regulates 2,3-BPG levels by converting it to 2-PG and its capacity has been estimated to be equal to BPGM capacity.

As described above, many proteins regulate the final affinity of $\mathrm{Hb}$ for oxygen and its delivery to the tissues, and should be considered as causative factors, which can contribute to the development of erythrocytosis if their function is impaired. The importance of channels and transporters, allowing the translocation of $\mathrm{Hb}$ allosteric regulators to and out of erythrocytes, has to be emphasized. Besides, enzyme deficiencies distal to the 2,3-BPG step in the Embden-Meyerhof glycolytic pathway, such as HK, GPI, aldolase, and TPI, can also cause a decrease in 2,3-BPG levels and could thus contribute to erythrocytosis. The same applies to MIPP1, the second enzyme of Rapoport-Luebbering shunt with 2,3BPG phosphatase activity, and PGK, an enzyme catalyzing the reversible conversion of 1,3-BPG to 3-PG $[115,136]$. Furthermore, erythrocyte metabolic adaptation to high-altitude hypoxia was recently reported to be regulated by an intracellular sphingolipid sphingosine 1-phosphate (S1P), a versatile bioactive intermediate metabolite of sphingosine. S1P is generated by sphingosine kinase 1 (SphK1) and SphK2, and irreversibly degraded by specific phosphatases or lyases. However, mature erythrocytes contain only Sphk1 but no S1P degrading enzymes, so they contain a much higher level of S1P. S1P has been shown to induce $\mathrm{O}_{2}$ release by direct binding to $\mathrm{Hb}$, promoting anchoring of deoxygenated $\mathrm{Hb}$ to the membrane and consequently enhancing the release of membrane-bound glycolytic enzymes to the cytosol, inducing glycolysis and the production of 2,3-BPG [134]. Therefore, the contribution of this mechanism to the development of erythrocytosis should be further investigated.

\section{Other Molecular Pathways Involved in Congenital Erythrocytosis}

\subsection{Regulation of Red Blood Cells Production and Degradation}

Besides previously described regulation by oxygen sensing and EPO signaling, erythropoiesis is tightly controlled also by several other hormones and pathways directly or indirectly involved in erythrocyte maturation and degradation $[124,125,137]$.

The potential new candidate that may contribute to the development of erythrocytosis are therefore hormones and their receptors that influence proliferation, survival and differentiation of erythrocytes, including macrophage colony-stimulating factor 1 (CSF1/CSF1R), Granulocyte-Macrophage Colony-Stimulating Factor 2 (CSF2/CSF2R) and interleukin 3 (IL3/IL3R). Several transcription factors in which dysregulation may also contribute to disease development are reviewed by Parisi et al. (2021) [138]. The Growth Factor Independent 1B Transcriptional Repressor (GFI1B) was confirmed as a novel candidate gene involved in the development of erythrocytosis in one of the previous studies [14]. Factors blocking the apoptosis of pre-erythrocytes should also be considered further, including regulation of autophagy, eryptosis and neocytolysis $[139,140]$.

In addition to increased production of mature erythrocytes, reduced clearance of senescent erythrocytes may also contribute to the development of erythrocytosis [137].

\subsection{Iron Metabolism}

Being a component of heme, iron-sulfur proteins, and other enzymes, iron is required in many biological mechanisms, including oxygen transport, energy production, DNA synthesis, and cellular respiration [141]. Apart from EPO, iron is also a critical component for the production of mature erythrocytes. It is involved in hemoglobin synthesis, as well as it regulates the proliferation and differentiation of erythroblasts [142]. Most of the iron in the body is bound to $\mathrm{Hb}$ in erythrocytes, while blood plasma contains transferrin (TF) bound to iron, which is the exclusive source of iron for erythropoiesis in the bone marrow [143].

The stable concentration of circulating iron is maintained by dietary absorption, storage, and recycling from senescent red blood cells in macrophages [142]. Iron is stored in cytoplasmic ferritin (FT) in hepatocytes and macrophages of the liver and spleen and 
is readily mobilized when iron demand is increased [143]. Dietary absorption is tightly regulated by the small intestine wherein the iron uptake into the enterocyte depends on apical iron divalent metal transporter 1 (DMT1), and transition of iron to transferrin in the blood circulation depends on basolateral membrane exporter ferroportin (FPN) $[143,144]$. However, ferroportin and hormone hepcidin (HAMP) are two master regulators that maintain systemic iron metabolism and homeostasis. When hepcidin binds to ferroportin, this causes ferroportin degradation and consequently limits iron transport into the circulation. Hepcidin is predominately synthesized by the liver and abundantly produced in excess iron concentrations, while tissue hypoxia, iron deficiency, and ineffective erythropoiesis are the factors responsible for decreased transcription and production of hepcidin to enable ferroportin stabilization [141-143,145]. Hepcidin synthesis is regulated by SMAD signaling through several proteins and receptors, including transferrin receptor 1 (TFR1) and TFR2, and hemochromatosis protein (HFE) [141]. HFE forms a complex with TFR1 and TFR2. TRF2 functions as a sensor for the circulating transferrin-bound iron, and it is highly expressed in the liver. TFR1 is responsible for iron uptake from plasma transferrin to the cells and is ubiquitously expressed in most of the cells, especially in erythroid precursors $[146,147]$. However, in erythrocyte production, hepcidin synthesis is additionally regulated through erythroferrone hormone (ERFE) secreted by EPO-stimulated erythroblasts in JAK2/STAT5 dependent manner [141,147].

Being sensitive to cellular iron and oxygen levels, HIF $2 \alpha$ has been reported as an essential factor to maintain systemic iron levels by regulating the transcription of genes encoding iron transporters, including DMT1 and FPN $[144,148]$. As demonstrated by Schwartz et al. (2019) [145], intestinal HIF2 $\alpha$ also controls iron uptake during iron deficiency and hypoxia, and drives iron absorption during iron overload. Iron is a cofactor for PHD enzymes, and HIF2 $\alpha$ stability and transcriptional response are regulated through hepcidin and ferroportin interaction that limits the activity of iron-dependent PHDs. Intestinal HIF $2 \alpha$ signaling is activated during erythropoiesis and it has been shown to be critical for the increase in serum iron, necessary for efficient erythropoiesis [144].

The expression of transcripts of iron metabolism proteins that contain iron-responsive elements (IRE) sequences, such as TFR1, DMT1, FPN, and ferritin, is post-transcriptionally controlled by two cytosolic iron regulatory proteins, IRP1 and IRP2 [141,149]. In irondeficient cells, IRPs bind with high affinity to IRE. HIF $2 \alpha$ also contains an IRE sequence and it has been reported that the expression of HIF $2 \alpha$ mRNA is exclusively regulated by IRP1, as IRP1-/- but not IRP2-/- mice developed erythrocytosis due to increased expression of EPO $[149,150]$. The involvement of TFR2 in erythropoiesis through its influence on EPOR signaling and terminal differentiation of erythroid progenitors has also been demonstrated. During the differentiation process, TFR2 and EPOR are co-expressed and TFR2 associates with EPOR in the endoplasmic reticulum for efficient transport of EPOR to the cell surface [146]. Furthermore, it has been proposed that HFE/TRF2 complex can potentiate MAPK signaling [143], and TFR1 can modulate EPO-dependent MAPK and PI3K signaling [73]. The connection of iron metabolic genes and erythrocytosis has also been demonstrated by a study by Biagetti et al. (2018) [12], where mutations in HFE were found in a relevant number of patients with idiopathic erythrocytosis. High incidence of HFE mutations in idiopathic erythrocytosis was indicated by several studies and the HFE gene together with other genes regulating iron metabolism (HJV, HAMP, TFR2, SLC40A1, FTH1, TF, B2 M, CP , FTL, CDAN1, SEC23B, SLC25A38, STEAP3, and ALAS2) were included in the genetic testing panel in our recent study [121,151]. Furthermore, decreased expression of hepcidin and increased expression of TFR1 and ERFE were observed in a transgenic mouse model with a JAK2 exon 12 mutation, frequently identified in patients with PV. High ERFE and low hepcidin together with elevated TFR1 enhance iron delivery to the sites of hematopoiesis to allow maximal production of red cells [152]. 


\subsection{Other Mechanisms}

It is well documented that testosterone therapy induces erythrocytosis [2,153]. In males normal values of hemoglobin are naturally higher, which confirms the assumption. Testosterone goes directly into the cell where it transforms into DHT (Dihydrotestosterone), with the help of 5- $\alpha$ reductase. DHT binds to the androgen receptor and together they are translocated into the cell nucleus, where dimer AR activates transcription of genes under the control of AR. The effect of other hormones, such as estrogen, growth hormone, thyroid hormones should also be addressed.

Genes involved in the metabolism of metals cobalt, nickel and manganese (SLC30A10), calcium (PIEZO1) and chloride ions must be carefully revised. Transcription of the erythropoietin may be modulated by metals (cobalt and nickel), which can substitute iron in the porphyrin ring [154].

Environmental manganese $(\mathrm{Mn})$ is toxic to the body, therefore manganese transporter encoded by Solute Carrier Family 30 Member 10 (SLC30A10) is crucial to maintain an appropriate manganese level in the body. Mutations in SLC30A10 were associated with Syndrome of Hepatic Cirrhosis, Dystonia, Polycythemia and Hypermanganesemia [155]. Therefore, the level of Mn and mutations of SLC30A10 should be revised in erythrocytosis patients.

Several recent publications have suggested the role of protein Piezo Type Mechanosensitive Ion Channel Component 1 (PIEZO1), the nonselective cation channel located on the membrane of the erythrocytes, which is activated by mechanic pressure. The gain-offunction mutation of gene encoding this channel was found in some cases of idiopathic erythrocytosis and xerocytosis [156-158]. Individuals with hereditary xerocytosis develop age-onset iron overload, linking the PIEZO1 to iron metabolism [159]. Another study suggests the role of PIEZO1 in the response of erythrocytes to mechanical stress and indicates its role also in early erythropoiesis [160].

\section{Conclusions}

Erythrocytosis is a rare hematological disorder that arises from an imbalance in homeostatic mechanisms of erythropoiesis and oxygen homeostasis. The main regulatory pathways in the process of oxygen homeostasis are still poorly understood, but this knowledge is necessary to identify new potential causative factors and to improve the current diagnostic methods. This review aimed to discover additional molecular mechanisms correlated with erythropoiesis and therefore erythrocytosis. We identified genes involved in post-translational modifications, nuclear and membrane transport, transcriptional regulation, positive and negative regulatory mechanisms of signal transduction, and erythrocyte glucose metabolism, which can modulate the stability or activity of key erythropoiesis genes, including EPAS1, EPO, EPOR, $H B A$ and $H B B$, and their partners, and consequently influence the process of erythrocyte production. Besides, several studies have demonstrated the interplay between disrupted iron homeostasis and erythrocytosis. Since iron is a critical component in the process of erythrocyte production, this represents another possible connection to erythrocytosis of unknown cause that should be further investigated. Epigenetics may also contribute to the development of disease. It must be taken into account, that besides monogenic, digenic or polygenic origin of the disorder shall also be addressed. Targets identified within this in silico review however need to be identified and confirmed on clinical samples and tested by functional analysis.

The diagnostic workflow should begin with a detailed review of clinical data and exclusion of any acquired cases for erythrocytosis; such as compensatory erythrocytosis due to chronic disease or polycythemia vera due to a JAK2 mutation. Only patients who remain idiopathic should undergo targeted NGS genetic testing covering all genes previously associated with erythrocytosis. In addition to sequencing exome region, attention should be paid to noncoding regions, including $5^{\prime}$ and $3^{\prime}$ UTRs, promoters, enhancers, introns and miRNA binding sites. If no disease driving genetic variant is identified, families with multiple members with erythrocytosis should be referred for whole-exome sequencing (WES) or whole-genome sequencing (WGS). Newly identified variants should be confirmed 
as causative by functional analysis. Attention shall be addressed to cumulative effect of several variants.

The limit of the current studies is, that the role of several molecules is studied in detail in cancer, while the information on the normal tissue is not available. Therefore, their enrolment in the regulatory mechanisms in healthy tissue must be considered with caution. However, mathematical modeling will expedite future research, as a model of all pathways will facilitate to understand the roles of specific genes/gene networks in the development of erythrocytosis.

Author Contributions: Conceptualization, N.D.; formal analysis, J.T.; data curation, J.T. and N.D.; writing—original draft preparation, J.T.; writing—review and editing, N.D.; supervision, N.D.; funding acquisition, N.D. Both authors have read and agreed to the published version of the manuscript.

Funding: This research was funded by Slovenian Research Agency, Grant Number: L3-9279 and P1-0390.

Institutional Review Board Statement: Not applicable.

Informed Consent Statement: Not applicable.

Data Availability Statement: Not applicable.

Conflicts of Interest: The authors declare no conflict of interest.

\section{References}

1. Bento, C. Genetic Basis of Congenital Erythrocytosis. Int. J. Lab. Hematol. 2018, 40, 62-67. [CrossRef]

2. Gašperšič, J.; Kristan, A.; Kunej, T.; Preložnik Zupan, I.; Debeljak, N. Erythrocytosis: Genes and Pathways Involved in Disease Development. Blood Transfus. 2020. [CrossRef]

3. McMullin, M.F. Genetic Background of Congenital Erythrocytosis. Genes 2021, 12, 1151. [CrossRef]

4. Jassal, B.; Matthews, L.; Viteri, G.; Gong, C.; Lorente, P.; Fabregat, A.; Sidiropoulos, K.; Cook, J.; Gillespie, M.; Haw, R.; et al. The Reactome Pathway Knowledgebase. Nucleic Acids Res. 2020, 48, D498-D503. [CrossRef]

5. Szklarczyk, D.; Franceschini, A.; Wyder, S.; Forslund, K.; Heller, D.; Huerta-Cepas, J.; Simonovic, M.; Roth, A.; Santos, A.; Tsafou, K.P.; et al. STRING V10: Protein-Protein Interaction Networks, Integrated over the Tree of Life. Nucleic Acids Res. 2015, 43, D447-D452. [CrossRef]

6. Consortium, T.U. UniProt: The Universal Protein Knowledgebase in 2021. Nucleic Acids Res. 2021, 49, D480-D489. [CrossRef]

7. Stelzer, G.; Rosen, N.; Plaschkes, I.; Zimmerman, S.; Twik, M.; Fishilevich, S.; Iny Stein, T.; Nudel, R.; Lieder, I.; Mazor, Y.; et al. The GeneCards Suite: From Gene Data Mining to Disease Genome Sequence Analyses. Curr. Protoc. Bioinform. 2016, 54, 1-30. [CrossRef] [PubMed]

8. Uhlen, M.; Oksvold, P.; Fagerberg, L.; Lundberg, E.; Jonasson, K.; Forsberg, M.; Zwahlen, M.; Kampf, C.; Wester, K.; Hober, S.; et al. Towards a Knowledge-Based Human Protein Atlas. Nat. Biotechnol. 2010, 28, 1248-1250. [CrossRef]

9. NCBI, R.C. Database Resources of the National Center for Biotechnology Information. Nucleic Acids Res. 2016, 44, D7-D19. [CrossRef]

10. Tweedie, S.; Braschi, B.; Gray, K.; Jones, T.E.M.; Seal, R.L.; Yates, B.; Bruford, E.A. Genenames.Org: The HGNC and VGNC Resources in 2021. Nucleic Acids Res. 2021, 49, D939-D946. [CrossRef] [PubMed]

11. Beutler, E.; Westwood, B.; Van Zwieten, R.; Roos, D. G $\rightarrow$ t Transition at Cdna Nt 110 (K37q) in the Pklr (Pyruvate Kinase) Gene Is the Molecular Basis of a Case of Hereditary Increase of Red Blood Cell Atp. Hum. Mutat. 1997, 9, 282-285. [CrossRef]

12. Biagetti, G.; Catherwood, M.; Robson, N.; Bertozzi, I.; Cosi, E.; McMullin, M.F.; Randi, M.L. HFE Mutations in Idiopathic Erythrocytosis. Br. J. Haematol. 2018, 181, 270-272. [CrossRef]

13. Lappin, T.R.; Lee, F.S. Update on Mutations in the HIF: EPO Pathway and Their Role in Erythrocytosis. Blood Rev. 2019, 37, 100590. [CrossRef]

14. Camps, C.; Petousi, N.; Bento, C.; Cario, H.; Copley, R.R.; McMullin, M.F.; Van Wijk, R.; Ratcliffe, P.J.; Robbins, P.A.; Taylor, J.C. Gene Panel Sequencing Improves the Diagnostic Work-up of Patients with Idiopathic Erythrocytosis and Identifies New Mutations. Haematologica 2016, 101, 1306-1318. [CrossRef]

15. Zmajkovic, J.; Lundberg, P.; Nienhold, R.; Torgersen, M.L.; Sundan, A.; Waage, A.; Skoda, R.C. A Gain-of-Function Mutation in EPO in Familial Erythrocytosis. N. Engl. J. Med. 2018, 378, 924-930. [CrossRef] [PubMed]

16. Lenglet, M.; Robriquet, F.; Schwarz, K.; Camps, C.; Couturier, A.; Hoogewijs, D.; Buffet, A.; Knight, S.; Gad, S.; Couvé, S.; et al Identification of a new VHL exon and complex splicing alterations in familial erythrocytosis or von Hippel-Lindau disease. Blood 2018, 132, 469-483. [CrossRef]

17. Tomc, J.; Debeljak, N. Molecular Insights into the Oxygen-Sensing Pathway and Erythropoietin. Int. J. Mol. Sci. 2021, $22,7074$. [CrossRef] [PubMed] 
18. Laureau, M.O. SMART Servier Medical Art. Les Laboratories Servier. Available online: https://smart.servier.com (accessed on 16 July 2021).

19. Moniz, S.; Bandarra, D.; Biddlestone, J.; Campbell, K.J.; Komander, D.; Bremm, A.; Rocha, S. Cezanne Regulates E2F1-Dependent HIF2 $\alpha$ Expression. J. Cell Sci. 2015, 128, 3082-3093. [CrossRef] [PubMed]

20. Wada, T.; Shimba, S.; Tezuka, M. Transcriptional Regulation of the Hypoxia Inducible Factor-2 $\alpha$ (HIF-2 $\alpha$ ) Gene during Adipose Differentiation in 3T3-L1 Cells. Biol. Pharm. Bull. 2006, 29, 49-54. [CrossRef] [PubMed]

21. Ligęza, J.; Marona, P.; Gach, N.; Lipert, B.; Miekus, K.; Wilk, W.; Jaszczyński, J.; Stelmach, A.; Loboda, A.; Dulak, J.; et al. MCPIP1 Contributes to Clear Cell Renal Cell Carcinomas Development. Angiogenesis 2017, 20. [CrossRef] [PubMed]

22. Xu, X.H.; Bao, Y.; Wang, X.; Yan, F.; Guo, S.; Ma, Y.; Xu, D.; Jin, L.; Xu, J.; Wang, J. Hypoxic-Stabilized EPAS1 Proteins Transactivate DNMT1 and Cause Promoter Hypermethylation and Transcription Inhibition of EPAS1 in Non-Small Cell Lung Cancer. FASEB J. 2018, 32, 6694-6705. [CrossRef] [PubMed]

23. Metzen, E.; Stiehl, D.P.; Doege, K.; Marxsen, J.H.; Hellwig-Bürgel, T.; Jelkmann, W. Regulation of the Prolyl Hydroxylase Domain Protein 2 (Phd2/Egln-1) Gene: Identification of a Functional Hypoxia-Responsive Element. Biochem. J. 2005, 387, $711-717$. [CrossRef] [PubMed]

24. Wielockx, B.; Meneses, A. PHD2: From Hypoxia Regulation to Disease Progression. Hypoxia 2016, 53. [CrossRef] [PubMed]

25. McMahon, S.; Charbonneau, M.; Grandmont, S.; Richard, D.E.; Dubois, C.M. Transforming Growth Factor B1 Induces HypoxiaInducible Factor-1 Stabilization through Selective Inhibition of PHD2 Expression. J. Biol. Chem. 2006, 281, 24171-24181. [CrossRef] [PubMed]

26. Zatyka, M.; Morrissey, C.; Kuzmin, I.; Lerman, M.I.; Latif, F.; Richards, F.M.; Maher, E.R. Genetic and Functional Analysis of the von Hippel-Lindau (VHL) Tumour Suppressor Gene Promoter. J. Med. Genet. 2002, 39, 463-472. [CrossRef]

27. Liu, X.; Cai, X.; Hu, B.; Mei, Z.; Zhang, D.; Ouyang, G.; Wang, J.; Zhang, W.; Xiao, W. Forkhead Transcription Factor 3a (FOXO3a) Modulates Hypoxia Signaling via up-Regulation of the von Hippel-Lindau Gene (VHL). J. Biol. Chem. 2016, 291, 25692-25705. [CrossRef] [PubMed]

28. Łuczak, M.W.; Roszak, A.; Pawlik, P.; Kędzia, H.; Lianeri, M.; Jagodziński, P.P. Increased Expression of HIF-1A and Its Implication in the Hypoxia Pathway in Primary Advanced Uterine Cervical Carcinoma. Oncol. Rep. 2011, 26, 1259-1264. [CrossRef] [PubMed]

29. Galson, D.L.; Tsuchiya, T.; Tendler, D.S.; Huang, L.E.; Ren, Y.; Ogura, T.; Bunn, H.F. The Orphan Receptor Hepatic Nuclear Factor 4 Functions as a Transcriptional Activator for Tissue-Specific and Hypoxia-Specific Erythropoietin Gene Expression and Is Antagonized by EAR3/COUP-TF1. Mol. Cell. Biol. 1995, 15, 2135-2144. [CrossRef]

30. Makita, T.; Hernandez-Hoyos, G.; Chen, T.H.P.; Wu, H.; Rothenberg, E.V.; Sucov, H.M. A Developmental Transition in Definitive Erythropoiesis: Erythropoietin Expression Is Sequentially Regulated by Retinoic Acid Receptors and HNF4. Genes Dev. 2001, 15, 889-901. [CrossRef]

31. Wang, F.; Zhang, R.; Wu, X.; Hankinson, O. Roles of Coactivators in Hypoxic Induction of the Erythropoietin Gene. PLoS ONE 2010, 5. [CrossRef]

32. Imagawa, S.; Yamamoto, M.; Miura, Y. Negative Regulation of the Erythropoietin Gene Expression by the GATA Transcription Factors. Blood 1997, 89, 1430-1439. [CrossRef] [PubMed]

33. Obara, N.; Suzuki, N.; Kim, K.; Nagasawa, T.; Imagawa, S.; Yamamoto, M. Repression via the GATA Box Is Essential for Tissue-Specific Erythropoietin Gene Expression. Blood 2008, 111, 5223-5232. [CrossRef]

34. Yin, H.; Blachard, K.L. Erratum: DNA Methylation Represses the Expression of the Human Erythropoietin Gene by Two Different Mechanisms. Blood 2000, 95, 111-119. [CrossRef] [PubMed]

35. Dengler, V.L.; Galbraith, M.; Espinosa, J.M. Transcriptional Regulation by Hypoxia Inducible Factors. Crit. Rev. Biochem. Mol. Biol. 2014, 49, 1-15. [CrossRef]

36. Gradin, K.; Takasaki, C.; Fujii-kuriyama, Y.; Sogawa, K. The Transcriptional Activation Function of the HIF-like Factor Requires Phosphorylation at a Conserved Threonine. J. Biol. Chem. 2002, 277, 23508-23514. [CrossRef] [PubMed]

37. Pangou, E.; Befani, C.; Mylonis, I.; Samiotaki, M.; Panayotou, G.; Simos, G.; Liakos, P. HIF-2 $\alpha$ Phosphorylation by CK1 $\delta$ Promotes Erythropoietin Secretion in Liver Cancer Cells under Hypoxia. J. Cell Sci. 2016, 129, 4213-4226. [CrossRef] [PubMed]

38. Dioum, E.M.; Chen, R.; Alexander, M.S.; Zhang, Q.; Hogg, R.T.; Gerard, R.D.; Garcia, J.A. Regulation of Hypoxia-Inducible Factor $2 \alpha$ Signaling by the Stress-Responsive Deacetylase Sirtuin 1. Science 2009, 324, 1289-1293. [CrossRef]

39. Bouras, T.; Fu, M.; Sauve, A.A.; Wang, F.; Quong, A.A.; Perkins, N.D.; Hay, R.T.; Gu, W.; Pestell, R.G. SIRT1 Deacetylation and Repression of P300 Involves Lysine Residues 1020/1024 within the Cell Cycle Regulatory Domain 1. J. Biol. Chem. 2005, 280, 10264-10276. [CrossRef]

40. Yang, M.; Zhu, M.; Song, K.; Wuren, T.; Yan, J.; Ge, R.-L.; Ji, L.; Cui, S. VHL Gene Methylation Contributes to Excessive Erythrocytosis in Chronic Mountain Sickness Rat Model by Upregulating the HIF-2 $\alpha$ /EPO Pathway. Life Sci. 2021, $266,118873$. [CrossRef]

41. Kubaichuk, K.; Kietzmann, T. Involvement of E3 Ligases and Deubiquitinases in the Control of HIF- $\alpha$ Subunit Abundance. Cells 2019, 8, 598. [CrossRef] [PubMed]

42. $\quad$ van Hagen, M.; Overmeer, R.M.; Abolvardi, S.S.; Vertegaal, A.C.O. RNF4 and VHL Regulate the Proteasomal Degradation of SUMO-Conjugated Hypoxia-Inducible Factor-2 $\alpha$. Nucleic Acids Res. 2009, 38, 1922-1931. [CrossRef] [PubMed]

43. Huang, C.; Han, Y.; Wang, Y.; Sun, X.; Yan, S.; Yeh, E.T.H.; Chen, Y.; Cang, H.; Li, H.; Shi, G.; et al. SENP3 Is Responsible for HIF-1 Transactivation under Mild Oxidative Stress via P300 de-SUMOylation. EMBO J. 2009, 28, 2748-2762. [CrossRef] [PubMed] 
44. Lisy, K.; Peet, D.J. Turn Me on: Regulating HIF Transcriptional Activity. Cell Death Differ. 2008, 15, 642-649. [CrossRef] [PubMed]

45. Montagner, M.; Enzo, E.; Forcato, M.; Zanconato, F.; Parenti, A.; Rampazzo, E.; Basso, G.; Leo, G.; Rosato, A.; Bicciato, S.; et al. SHARP1 Suppresses Breast Cancer Metastasis by Promoting Degradation of Hypoxia-Inducible Factors. Nature 2012, 487, 380-384. [CrossRef]

46. Barth, S.; Nesper, J.; Hasgall, P.A.; Wirthner, R.; Nytko, K.J.; Edlich, F.; Katschinski, D.M.; Stiehl, D.P.; Wenger, R.H.; Camenisch, G. The Peptidyl Prolyl Cis/Trans Isomerase FKBP38 Determines Hypoxia-Inducible Transcription Factor Prolyl-4-Hydroxylase PHD2 Protein Stability. Mol. Cell. Biol. 2007, 27, 3758-3768. [CrossRef] [PubMed]

47. Baek, J.H.; Mahon, P.C.; Oh, J.; Kelly, B.; Krishnamachary, B.; Pearson, M.; Chan, D.A.; Giaccia, A.J.; Semenza, G.L. OS-9 Interacts with Hypoxia-Inducible Factor $1 \alpha$ and Prolyl Hydroxylases to Promote Oxygen-Dependent Degradation of HIF-1 $\alpha$. Mol. Cell 2005, 17, 503-512. [CrossRef]

48. Kumar, P.; Gullberg, U.; Olsson, I.; Ajore, R. Myeloid Translocation Gene-16 Co-Repressor Promotes Degradation of HypoxiaInducible Factor 1. PLoS ONE 2015, 10, e0123725. [CrossRef]

49. Minervini, G.; Quaglia, F.; Tosatto, S.C.E. Computational Analysis of Prolyl Hydroxylase Domain-Containing Protein 2 (PHD2) Mutations Promoting Polycythemia Insurgence in Humans. Sci. Rep. 2016, 6, 1-9. [CrossRef]

50. Baek, J.H.; Liu, Y.V.; McDonald, K.R.; Wesley, J.B.; Hubbi, M.E.; Byun, H.; Semenza, G.L. Spermidine/Spermine-N1Acetyltransferase 2 Is an Essential Component of the Ubiquitin Ligase Complex That Regulates Hypoxia-Inducible Factor 1alpha. J. Biol. Chem. 2007, 282, 23572-23580. [CrossRef]

51. Gossage, L.; Eisen, T.; Maher, E.R. VHL, the Story of a Tumour Suppressor Gene. Nat. Rev. Cancer 2015, 15, 55-64. [CrossRef]

52. Cardote, T.A.F.; Gadd, M.S.; Ciulli, A. Crystal Structure of the Cul2-Rbx1-EloBC-VHL Ubiquitin Ligase Complex. Structure 2017, 25, 901-911.e3. [CrossRef] [PubMed]

53. Partch, C.L.; Gardner, K.H. Coactivators Necessary for Transcriptional Output of the Hypoxia Inducible Factor, HIF, Are Directly Recruited by ARNT PAS-B. Proc. Natl. Acad. Sci. USA 2011, 108, 7739-7744. [CrossRef]

54. Depping, R.; Jelkmann, W.; Kosyna, F.K. Nuclear-Cytoplasmatic Shuttling of Proteins in Control of Cellular Oxygen Sensing. J. Mol. Med. 2015, 93, 599-608. [CrossRef] [PubMed]

55. Depping, R.; Steinhoff, A.; Schindler, S.G.; Friedrich, B.; Fagerlund, R.; Metzen, E.; Hartmann, E.; Köhler, M. Nuclear Translocation of Hypoxia-Inducible Factors (HIFs): Involvement of the Classical Importin $\alpha / \beta$ Pathway. Biochim. Biophys. Acta Mol. Cell Res. 2008, 1783, 394-404. [CrossRef]

56. Gkotinakou, I.M.; Befani, C.; Simos, G.; Liakos, P. ERK1/2 Phosphorylates HIF-2 $\alpha$ and Regulates Its Activity by Controlling Its CRM1-Dependent Nuclear Shuttling. J. Cell Sci. 2019, 132, 1-13. [CrossRef] [PubMed]

57. Khacho, M.; Mekhail, K.; Pilon-Larose, K.; Pause, A.; Cote, J.; Lee, S. EEF1A Is a Novel Component of the Mammalian Nuclear Protein Export Machinery. Mol. Biol. Cell 2008, 19, 5296-5308. [CrossRef]

58. Chin, H.; Arai, A.; Wakao, H.; Kamiyama, R.; Miyasaka, N.; Miura, O. Lyn Physically Associates with the Erythropoietin Receptor and May Play a Role in Activation of the Stat5 Pathway. Blood 1998, 91, 3734-3745. [CrossRef]

59. Laubach, J.P.; Fu, P.; Jiang, X.; Salter, K.H.; Potti, A.; Arcasoy, M.O. Polycythemia Vera Erythroid Precursors Exhibit Increased Proliferation and Apoptosis Resistance Associated with Abnormal RAS and PI3K Pathway Activation. Exp. Hematol. 2009, 37, 1411-1422. [CrossRef]

60. Debeljak, N.; Solár, P.; Sytkowski, A.J. Erythropoietin and Cancer: The Unintended Consequences of Anemia Correction. Front. Immunol. 2014, 5, 1-14. [CrossRef]

61. Tóthová, Z.; Tomc, J.; Debeljak, N.; Solar, P. STAT5 as a Key Protein of Erythropoietin Signalization. Int. J. Mol. Sci. 2021, 22, 7109. [CrossRef]

62. Tóthová, Z.; Šemeláková, M.; Solárová, Z.; Tomc, J.; Debeljak, N.; Solár, P. The Role of PI3K/AKT and MAPK Signaling Pathways in Erythropoietin Signalization. Int. J. Mol. Sci. 2021, 22, 7682. [CrossRef] [PubMed]

63. Vočanec, D.; Prijatelj, T.; Debeljak, N.; Kunej, T. Genetic Variants of Erythropoietin (EPO) and EPO Receptor Genes in Familial Erythrocytosis. Int. J. Lab. Hematol. 2019, 41, 162-167. [CrossRef] [PubMed]

64. Hodges, V.M.; Rainey, S.; Lappin, T.R.; Maxwell, A.P. Pathophysiology of Anemia and Erythrocytosis. Crit. Rev. Oncol. Hematol. 2007, 64, 139-158. [CrossRef] [PubMed]

65. Spolverini, A.; Pieri, L.; Guglielmelli, P.; Pancrazzi, A.; Fanelli, T.; Paoli, C.; Bosi, A.; Nichele, I.; Ruggeri, M.; Vannucchi, A.M. Infrequent Occurrence of Mutations in the PH Domain of LNK in Patients with JAK2 Mutation-Negative "idiopathic" Erythrocytosis. Haematologica 2013, 98, 101-102. [CrossRef] [PubMed]

66. McMullin, M.F.; Cario, H. LNK mutations and myeloproliferative disorders. Am. J. Hematol. 2016, 91, 248-251. [CrossRef]

67. Jegalian, A.G.; Wu, H. Differential Roles of SOCS Family Members in EpoR Signal Transduction. J. Interf. Cytokine Res. 2002, 22, 853-860. [CrossRef]

68. Kapralova, K.; Horvathova, M.; Pecquet, C.; Fialova Kucerova, J.; Pospisilova, D.; Leroy, E.; Kralova, B.; Milosevic Feenstra, J.D.; Schischlik, F.; Kralovics, R.; et al. Cooperation of germ line JAK2 mutations E846D and R1063H in hereditary erythrocytosis with megakaryocytic atypia. Blood 2016, 128, 1418-1423. [CrossRef] [PubMed]

69. Stuckey, R.; Gómez-Casares, T.G. Recent Advances in the Use of Molecular Analyses to Inform the Diagnosis and Prognosis of Patients with Polycythaemia Vera. Int. J. Mol. Sci. 2021, 22, 5042. [CrossRef] 
70. Merkle, R.; Steiert, B.; Salopiata, F.; Depner, S.; Raue, A.; Iwamoto, N.; Schelker, M.; Hass, H.; Wäsch, M.; Böhm, M.E.; et al. Identification of Cell Type-Specific Differences in Erythropoietin Receptor Signaling in Primary Erythroid and Lung Cancer Cells. PLoS Comput. Biol. 2016, 12, 1-34. [CrossRef]

71. Zon, L.I.; Youssoufian, H.; Mather, C.; Lodish, H.F.; Orkin, S.H. Activation of the Erythropoietin Receptor Promoter by Transcription Factor GATA-1. Proc. Natl. Acad. Sci. USA 1991, 88, 10638-10641. [CrossRef]

72. Chin, K.; Oda, N.; Shen, K.; Tom noguchi, C. Regulation of Transcription of the Human Erythropoietin Receptor Gene by Proteins Binding to GATA-1 and Sp1 Motifs. Nucleic Acids Res. 1995, 23, 3041-3049. [CrossRef]

73. Kuhrt, D.; Wojchowski, D.M. Emerging EPO and EPO Receptor Regulators and Signal Transducers. Blood 2015, $125,3536-3541$. [CrossRef]

74. Perreault, A.A.; Benton, M.L.; Koury, M.J.; Brandt, S.J.; Venters, B.J. Epo Reprograms the Epigenome of Erythroid Cells. Exp. Hematol. 2017, 51, 47-62. [CrossRef] [PubMed]

75. Perreaulta, A.A.; Venters, B.J. Integrative View on How Erythropoietin Signaling Controls Transcription Patterns in Erythroid Cells. Curr. Opin. Hematol. 2018, 25, 189-195. [CrossRef]

76. Maurer, B.; Kollmann, S.; Pickem, J.; Hoelbl-Kovacic, A.; Sexl, V. STAT5A and STAT5B—Twins with Different Personalities in Hematopoiesis and Leukemia. Cancers (Basel) 2019, 11, 1726. [CrossRef]

77. Watowich, S.S. The Erythropoietin Receptor: Molecular Structure and Hematopoietic Signaling Pathways. J. Investig. Med. 2011, 59, 1067-1072. [CrossRef]

78. Able, A.A.; Burrell, J.A.; Stephens, J.M. STAT5-Interacting Proteins: A Synopsis of Proteins That Regulate STAT5 Activity. Biology (Basel) 2017, 6, 20. [CrossRef] [PubMed]

79. Ernst, S.; Müller-Newen, G. Nucleocytoplasmic Shuttling of Stats. A Target for Intervention? Cancers (Basel) 2019, 11, 1815. [CrossRef]

80. Gillinder, K.R.; Tuckey, H.; Bell, C.C.; Magor, G.W.; Huang, S.; Ilsley, M.D.; Perkins, A.C. Direct Targets of PStat5 Signalling in Erythropoiesis. PLoS ONE 2017, 12, e0180922. [CrossRef] [PubMed]

81. Okutani, Y.; Kitanaka, A.; Tanaka, T.; Kamano, H.; Ohnishi, H.; Kubota, Y.; Ishida, T.; Takahara, J. Src Directly TyrosinePhosphorylates STAT5 on Its Activation Site and Is Involved in Erythropoietin-Induced Signaling Pathway. Oncogene 2001, 20, 6643-6650. [CrossRef]

82. Nagao, T.; Kurosu, T.; Umezawa, Y.; Nogami, A.; Oshikawa, G.; Tohda, S.; Yamamoto, M.; Miura, O. Proliferation and Survival Signaling from Both Jak2-V617F and Lyn Involving GSK3 and MTOR/P70S6K/4EBP1 in PVTL-1 Cell Line Newly Established from Acute Myeloid Leukemia Transformed from Polycythemia Vera. PLoS ONE 2014, 9. [CrossRef] [PubMed]

83. Ota, J.; Kimura, F.; Sato, K.; Wakimoto, N.; Nakamura, Y.; Nagata, N.; Suzu, S.; Yamada, M.; Shimamura, S.; Motoyoshi, K. Association of CrkL with STAT5 in Hematopoietic Cells Stimulated by Granulocyte-Macrophage Colony-Stimulating Factor or Erythropoietin. Biochem. Biophys. Res. Commun. 1998, 252, 779-786. [CrossRef]

84. Held, M.A.; Greenfest-allen, E.; Su, S.; Stoeckert, C.J.; Stokes, M.P.; Wojchowski, D.M. Phospho-PTM Proteomic Discovery of Novel EPO- Modulated Kinases and Phosphatases, Including PTPN18 as a Positive Regulator of EPOR/JAK2 Signaling. Cell. Signal. 2020, 69, 109554. [CrossRef]

85. Tong, W.; Zhang, J.; Lodish, H.F. Lnk Inhibits Erythropoiesis and Epo-Dependent JAK2 Activation and Downstream Signaling Pathways. Blood 2005, 105, 4604-4612. [CrossRef] [PubMed]

86. Klingmüller, U.; Lorenz, U.; Cantley, L.C.; Neel, B.G.; Lodish, H.F. Specific Recruitment of SH-PTP1 to the Erythropoietin Receptor Causes Inactivation of JAK2 and Termination of Proliferative Signals. Cell 1995, 80, 729-738. [CrossRef]

87. Ingley, E. Integrating Novel Signaling Pathways Involved in Erythropoiesis. IUBMB Life 2012, 64, 402-410. [CrossRef]

88. Wojchowski, D.M.; Sathyanarayana, P.; Dev, A. Erythropoietin Receptor Response Circuits. Curr. Opin. Hematol. 2010, 17, 169-176. [CrossRef]

89. Peltola, K.J.; Paukku, K.; Aho, T.L.T.; Ruuska, M.; Silvennoinen, O.; Koskinen, P.J. Pim-1 Kinase Inhibits STAT5-Dependent Transcription via Its Interactions with SOCS1 and SOCS3. Blood 2004, 103, 3744-3750. [CrossRef]

90. Xie, Y.; Shi, X.; Sheng, K.; Han, G.; Li, W.; Zhao, Q.; Jiang, B.; Feng, J.; Li, J.; Gu, Y. PI3K/Akt Signaling Transduction Pathway, Erythropoiesis and Glycolysis in Hypoxia (Review). Mol. Med. Rep. 2019, 19, 783-791. [CrossRef]

91. Bouscary, D.; Pene, F.; Claessens, Y.E.; Muller, O.; Chrétien, S.; Fontenay-Roupie, M.; Gisselbrecht, S.; Mayeux, P.; Lacombe, C. Critical Role for PI 3-Kinase in the Control of Erythropoietin-Induced Erythroid Progenitor Proliferation. Blood 2003, 101, 34363443. [CrossRef] [PubMed]

92. Jafari, M.; Ghadami, E.; Dadkhah, T.; Akhavan-Niaki, H. PI3k/AKT Signaling Pathway: Erythropoiesis and Beyond. J. Cell. Physiol. 2019, 234, 2373-2385. [CrossRef]

93. Verdier, F.; Chrétien, S.; Billat, C.; Gisselbrecht, S.; Lacombe, C.; Mayeux, P. Erythropoietin Induces the Tyrosine Phosphorylation of Insulin Receptor Substrate-2. An Alternate Pathway for Erythropoietin-Induced Phosphatidylinositol 3-Kinase Activation. J. Biol. Chem. 1997, 272, 26173-26178. [CrossRef] [PubMed]

94. Missiroli, S.; Etro, D.; Buontempo, F.; Ye, K.; Capitani, S.; Neri, L.M. Nuclear Translocation of Active AKT Is Required for Erythroid Differentiation in Erythropoietin Treated K562 Erythroleukemia Cells. Int. J. Biochem. Cell Biol. 2009, 41, 570-577. [CrossRef] [PubMed]

95. Leslie, N.R.; Biondi, R.M.; Alessi, D.R. Phosphoinositide-Regulated Kinases and Phosphoinositide Phosphatases. ChemInform 2010, 32. [CrossRef] 
96. Maira, S.M.; Galetic, I.; Brazil, D.P.; Kaech, S.; Ingley, E.; Thelen, M.; Hemmings, B.A. Carboxyl-Terminal Modulator Protein (CTMP), a Negative Regulator of PKB/Akt and v-Akt at the Plasma Membrane. Science 2001, 294, 374-380. [CrossRef] [PubMed]

97. Karayel, Ö.; Xu, P.; Bludau, I.; Velan Bhoopalan, S.; Yao, Y.; Ana Rita, F.C.; Santos, A.; Schulman, B.A.; Alpi, A.F.; Weiss, M.J.; et al. Integrative Proteomics Reveals Principles of Dynamic Phosphosignaling Networks in Human Erythropoiesis. Mol. Syst. Biol. 2020, 16, 1-22. [CrossRef]

98. Miura, Y.; Miura, O.; Ihle, J.N.; Aoki, N. Activation of the Mitogen-Activated Protein Kinase Pathway by the Erythropoietin Receptor. J. Biol. Chem. 1994, 269, 29962-29969. [CrossRef]

99. Arai, A.; Kanda, E.; Nosaka, Y.; Miyasaka, N.; Miura, O. CrkL Is Recruited through Its SH2 Domain to the Erythropoietin Receptor and Plays a Role in Lyn-Mediated Receptor Signaling. J. Biol. Chem. 2001, 276, 33282-33290. [CrossRef]

100. Mason, J.M.; Beattie, B.K.; Liu, Q.; Dumont, D.J.; Barber, D.L. The SH2 Inositol 5-Phosphatase Ship1 Is Recruited in an SH2Dependent Manner to the Erythropoietin Receptor. J. Biol. Chem. 2000, 275, 4398-4406. [CrossRef]

101. Tauchi, T.; Damen, J.E.; Toyama, K.; Feng, G.S.; Broxmeyer, H.E.; Krystal, G. Tyrosine 425 within the Activated Erythropoietin Receptor Binds Syp, Reduces the Erythropoietin Required for Syp Tyrosine Phosphorylation, and Promotes Mitogenesis. Blood 1996, 87, 4495-4501. [CrossRef]

102. Lee, J.T.; McCubrey, J.A. The Raf/Mek/Erk Signal Transduction Cascade as a Target for Chemotherapeutic Intervention in Leukemia. Leukemia 2002, 16, 486-507. [CrossRef] [PubMed]

103. Cargnello, M.; Roux, P.P. Activation and Function of the MAPKs and Their Substrates, the MAPK-Activated Protein Kinases. Microbiol. Mol. Biol. Rev. 2011, 75, 50-83. [CrossRef]

104. Pearson, G.; Robinson, F.; Gibson, T.B.; Xu, B.E.; Karandikar, M.; Berman, K.; Cobb, M.H. Mitogen-Activated Protein (MAP) Kinase Pathways: Regulation and Physiological Functions. Endocr. Rev. 2001, 22, 153-183. [CrossRef]

105. Wu, P.K.; Becker, A.; Park, J.I. Growth Inhibitory Signaling of the Raf/Mek/Erk Pathway. Int. J. Mol. Sci. 2020, 21, 5436. [CrossRef]

106. Maik-Rachline, G.; Hacohen-Lev-Ran, A.; Seger, R. Nuclear Erk: Mechanism of Translocation, Substrates, and Role in Cancer. Int. J. Mol. Sci. 2019, 20, 1194. [CrossRef]

107. Elorza, A.; Hyde, B.; Mikkola, H.K.; Collins, S.; Shirihai, O.S. UCP2 Modulates Cell Proliferation through the MAPK/ERK Pathway during Erythropoiesis and Has No Effect on Heme Biosynthesis. J. Biol. Chem. 2008, 283, 30461-30470. [CrossRef] [PubMed]

108. Chen, C.; Sytkowski, A.J. Erythropoietin Regulation of Raf-1 and MEK: Evidence for a Ras-Independent Mechanism. Blood 2004, 104, 73-80. [CrossRef] [PubMed]

109. Kumkhaek, C.; Aerbajinai, W.; Liu, W.; Zhu, J.; Uchida, N.; Kurlander, R.; Hsieh, M.M.; Tisdale, J.F.; Rodgers, G.P. MASL1 Induces Erythroid Differentiation in Human Erythropoietin-Dependent CD34+ Cells through the Raf/MEK/ERK Pathway. Blood 2013, 121, 3216-3227. [CrossRef]

110. Kondoh, K.; Nishida, E. Regulation of MAP Kinases by MAP Kinase Phosphatases. Biochim. Biophys. Acta Mol. Cell Res. 2007, 1773, 1227-1237. [CrossRef]

111. Mitin, N.; Rossman, K.L.; Der, C.J. Signaling Interplay in Ras Superfamily Function. Curr. Biol. 2005, 15, 563-574. [CrossRef] [PubMed]

112. Yeung, K.; Seitz, T.; Li, S.; Janosch, P.; McFerran, B.; Kaiser, C.; Fee, F.; Katsanakis, K.D.; Rose, D.W.; Mischak, H.; et al. Suppression of Raf-1 Kinase Activity and MAP Kinase Signalling by RKIP. Nature 1999, 401, 173-177. [CrossRef]

113. Yoshimura, A. Regulation of Cytokine Signaling by the SOCS and Spred Family Proteins. Keio J. Med. 2009, 58, 73-83. [CrossRef] [PubMed]

114. Singh, S.; Dev, A.; Verma, R.; Pradeep, A.; Sathyanarayana, P.; Green, J.M.; Narayanan, A.; Wojchowski, D.M. Defining an EPORRegulated Transcriptome for Primary Progenitors, Including Tnfr-Sf13c as a Novel Mediator of EPO- Dependent Erythroblast Formation. PLoS ONE 2012, 7, e38530. [CrossRef]

115. Van Wijk, R.; Van Solinge, W.W. The Energy-Less Red Blood Cell Is Lost: Erythrocyte Enzyme Abnormalities of Glycolysis. Blood 2005, 106, 4034-4042. [CrossRef] [PubMed]

116. Yudin, J.; Verhovsek, M. How we diagnose and manage altered oxygen affinity hemoglobin variants. Am. J. Hematol. 2019, 94, 597-603. [CrossRef] [PubMed]

117. Thom, C.S.; Dickson, C.F.; Gell, D.A.; Weiss, M.J. Hemoglobin Variants: Biochemical Properties and Clinical Correlates. Cold Spring Harb. Perspect. Med. 2013, 3, a011858. [CrossRef] [PubMed]

118. Bunn, H.F. Erythropoietin. Cold Spring Harb. Perspect. Med. 2013, 3, a011619. [CrossRef]

119. Tashi, T.; Song, J.; Prchal, J.T. Congenital and Evolutionary Modulations of Hypoxia Sensing and Their Erythroid Phenotype. Curr. Opin. Physiol. 2019, 7, 27-32. [CrossRef]

120. Vora, S.; Corash, L.; Engel, W.K.; Durham, S.; Seaman, C.; Piomelli, S. The Molecular Mechanism of the Inherited Phosphofructokinase Deficiency Associated with Hemolysis and Myopathy. Blood 1980, 55, 629-635. [CrossRef]

121. Kristan, A.; Pajič, T.; Maver, A.; Režen, T.; Kunej, T.; Količ, R.; Vuga, A.; Fink, M.; Žula, Š.; Podgornik, H.; et al. Identification of Variants Associated with Rare Hematological Disorder Erythrocytosis Using Targeted Next-Generation Sequencing Analysis. Front. Genet. 2021, 12, 232. [CrossRef]

122. Katsumura, K.R.; DeVilbiss, A.W.; Pope, N.J.; Johnson, K.D.; Bresnick, E.H. Transcriptional mechanisms underlying hemoglobin synthesis. Cold Spring Harb. Perspect. Med. 2013, 3, a015412. [CrossRef] [PubMed] 
123. Mairbaurl, H.; Humpeler, E. The Influence of Noradrenaline on the Oxygen Affinity of Hemoglobin. Pflugers Arch. Eur. J. Physiol. $1979,48,327-386$.

124. Fan, A.X.; Hossain, M.A.; Stees, J.; Gavrilova, E.; Bungert, J. Regulation of erythroid cell differentiation by transcription factors, chromatin structure alterations, and noncoding RNA. In Epigenetic Gene Expression and Regulation; Huang, S., Litt, M.D., Blakey, C., Eds.; Academic Press: Cambridge, MA, USA, 2015; p. 482.

125. Forget, B.G.; Franklin Bunn, H. Classification of the Disorders of Hemoglobin. Cold Spring Harb. Perspect. Med. 2013, 3, 1-12. [CrossRef] [PubMed]

126. Moradkhani, K.; Préhu, C.; Old, J.; Henderson, S.; Balamitsa, V.; Luo, H.Y.; Poon, M.C.; Chui, D.H.K.; Wajcman, H.; Patrinos, G.P. Mutations in the Paralogous Human $\alpha$-Globin Genes Yielding Identical Hemoglobin Variants. Ann. Hematol. 2009, 88, 535-543. [CrossRef] [PubMed]

127. Steinberg, M.H.; Rodgers, G.P. HbA2: Biology, Clinical Relevance and a Possible Target for Ameliorating Sickle Cell Disease. Br. J. Haematol. 2015, 170, 781-787. [CrossRef]

128. Nkya, S.; Nkya, S.; Mwita, L.; Mgaya, J.; Kumburu, H.; Van Zwetselaar, M.; Menzel, S.; Mazandu, G.K.; Mazandu, G.K.; Mazandu, G.K.; et al. Identifying Genetic Variants and Pathways Associated with Extreme Levels of Fetal Hemoglobin in Sickle Cell Disease in Tanzania. BMC Med. Genet. 2020, 21, 1-12. [CrossRef] [PubMed]

129. Thein, S.L.; Menzel, S. Discovering the Genetics Underlying Foetal Haemoglobin Production in Adults. Br. J. Haematol. 2009, 145, 455-467. [CrossRef]

130. McMullin, M.F. The Classification and Diagnosis of Erythrocytosis. Int. J. Lab. Hematol. 2008, 30, 447-459. [CrossRef]

131. De Rosa, M.C.; Alinovi, C.C.; Galtieri, A.; Scatena, R.; Giardina, B. The Plasma Membrane of Erythrocytes Plays a Fundamental Role in the Transport of Oxygen, Carbon Dioxide and Nitric Oxide and in the Maintenance of the Reduced State of the Heme Iron. Gene 2007, 398, 162-171. [CrossRef] [PubMed]

132. Hoyer, J.D.; Allen, S.L.; Beutler, E.; Kubik, K.; West, C.; Fairbanks, V.F. Erythrocytosis Due to Bisphosphoglycerate Mutase Deficiency with Concurrent Glucose-6-Phosphate Dehydrogenase (G-6-PD) Deficiency. Am. J. Hematol. 2004, 75, 205-208. [CrossRef]

133. Endeward, V.; Cartron, J.; Ripoche, P.; Gros, G. RhAG Protein of the Rhesus Complex Is a $\mathrm{CO}_{2}$ Channel in the Human Red Cell Membrane. FASEB J. 2008, 22, 64-73. [CrossRef]

134. Sun, K.; Zhang, Y.; D’Alessandro, A.; Nemkov, T.; Song, A.; Wu, H.; Liu, H.; Adebiyi, M.; Huang, A.; Wen, Y.E.; et al. Sphingosine1-Phosphate Promotes Erythrocyte Glycolysis and Oxygen Release for Adaptation to High-Altitude Hypoxia. Nat. Commun. 2016, 7, 1-13. [CrossRef]

135. Reithmeier, R.A.F.; Casey, J.R.; Kalli, A.C.; Sansom, M.S.P.; Alguel, Y.; Iwata, S. Band 3, the Human Red Cell Chloride/Bicarbonate Anion Exchanger (AE1, SLC4A1), in a Structural Context. Biochim. Biophys. Acta Biomembr. 2016, 1858, 1507-1532. [CrossRef]

136. Cho, J.; King, J.S.; Qian, X.; Harwood, A.J.; Shears, S.B. Dephosphorylation of 2,3-Bisphosphoglycerate by MIPP Expands the Regulatory Capacity of the Rapoport-Luebering Glycolytic Shunt. Proc. Natl. Acad. Sci. USA 2008, 105, 5998-6003. [CrossRef]

137. Rieger, M.; Schroeder, T. Hematopoiesis. Cold Spring Harb. Perspect. Biol. 2012, 4. [CrossRef] [PubMed]

138. Parisi, S.; Finelli, C.; Fazio, A.; De Stefano, A.; Mongiorgi, S.; Ratti, S.; Cappellini, A.; Billi, A.M.; Cocco, L.; Follo, M.Y.; et al. Clinical and Molecular Insights in Erythropoiesis Regulation of Signal Transduction Pathways in Myelodysplastic Syndromes and $\beta$-Thalassemia. Int. J. Mol. Sci. 2021, 22, 827. [CrossRef]

139. Lang, E.; Lang, F. Triggers, Inhibitors, Mechanisms, and Significance of Eryptosis: The Suicidal Erythrocyte Death. Biomed. Res. Int. 2015, 2015, 513518. [CrossRef] [PubMed]

140. Grosso, R.; Fader, C.; Colombo, M. Autophagy: A Necessary Event during Erythropoiesis. Blood Rev. 2017, 31, 300-305. [CrossRef] [PubMed]

141. Nairz, M.; Weiss, G. Iron in Health and Disease. Mol. Asp. Med. 2020, 75, 100906. [CrossRef]

142. Ginzburg, Y.Z.; Feola, M.; Zimran, E.; Varkonyi, J.; Ganz, T.; Hoffman, R. Dysregulated Iron Metabolism in Polycythemia Vera: Etiology and Consequences. Leukemia 2018, 32, 2105-2116. [CrossRef] [PubMed]

143. Ganz, T.; Nemeth, E. Hepcidin and Iron Homeostasis. Biochim. Biophys. Acta 2014, 1823, 1434-1443. [CrossRef]

144. Anderson, E.R.; Xue, X.; Shah, Y.M. Intestinal Hypoxia-Inducible Factor-2 $\alpha$ (HIF-2 $\alpha$ ) Is Critical for Efficient Erythropoiesis. J. Biol. Chem. 2011, 286, 19533-19540. [CrossRef]

145. Schwartz, A.J.; Das, N.K.; Ramakrishnan, S.K.; Jain, C.; Jurkovic, M.T.; Wu, J.; Nemeth, E.; Lakhal-Littleton, S.; Colacino, J.A.; Shah, Y.M. Hepatic Hepcidin/Intestinal HIF-2 $\alpha$ Axis Maintains Iron Absorption during Iron Deficiency and Overload. J. Clin. Investig. 2019, 129, 336-348. [CrossRef]

146. Forejtnikovà, H.; Vieillevoye, M.; Zermati, Y.; Lambert, M.; Pellegrino, R.M.; Guihard, S.; Gaudry, M.; Camaschella, C.; Lacombe, C.; Roetto, A.; et al. Transferrin Receptor 2 Is a Component of the Erythropoietin Receptor Complex and Is Required for Efficient Erythropoiesis. Blood 2010, 116, 5357-5367. [CrossRef] [PubMed]

147. Grootendorst, S.; de Wilde, J.; van Dooijeweert, B.; van Vuren, A.; van Solinge, W.; Schutgens, R.; van Wijk, R.; Bartels, M. The Interplay between Drivers of Erythropoiesis and Iron Homeostasis in Rare Hereditary Anemias: Tipping the Balance. Int. J. Mol. Sci. 2021, 22, 2204. [CrossRef] [PubMed]

148. Taylor, M.; Qu, A.; Anderson, E.R.; Matsubara, T.; Martin, A.; Gonzalez, F.J.; Shah, Y.M. Hypoxia-Inducible Factor-2 $\alpha$ Mediates the Adaptive Increase of Intestinal Ferroportin during Iron Deficiency in Mice. Gastroenterology 2011, 140, 2044-2055. [CrossRef] [PubMed] 
149. Ghosh, M.C.; Zhang, D.L.; Ollivierre, H.; Eckhaus, M.A.; Rouault, T.A. Translational Repression of HIF2 $\alpha$ Expression in Mice with Chuvash Polycythemia Reverses Polycythemia. J. Clin. Investig. 2018, 128, 1317-1325. [CrossRef]

150. Wilkinson, N.; Pantopoulos, K. IRP1 Regulates Erythropoiesis and Systemic Iron Homeostasis by Controlling HIF2 $\alpha$ MRNA Translation. Blood 2013, 122, 1658-1669. [CrossRef]

151. Burlet, B.; Bourgeois, V.; Buriller, C.; Aral, B.; Airaud, F.; Gardie, B.; Girodon, F. High HFE mutation incidence in idiopathic erythrocytosis. Br. J. Haematol. 2019, 185, 794-795. [CrossRef]

152. Grisouard, J.; Li, S.; Kubovcakova, L.; Rao, T.N.; Meyer, S.C.; Lundberg, P.; Hao-Shen, H.; Romanet, V.; Murakami, M.; Radimerski, T.; et al. JAK2 Exon 12 Mutant Mice Display Isolated Erythrocytosis and Changes in Iron Metabolism Favoring Increased Erythropoiesis. Blood 2016, 128, 839-851. [CrossRef] [PubMed]

153. Twitchell, D.K.; Pastuszak, A.W.; Khera, M. Controversies in Testosterone Therapy. Sex. Med. Rev. 2021, 9, 149-159. [CrossRef]

154. Bunn, H.F.; Gu, J.; Huang, L.E.; Park, J.W.; Zhu, H. Erythropoietin: A model system for studying oxygen-dependent gene regulation. J. Exp. Biol. 1998, 201 Pt 8, 1197-1201. [CrossRef]

155. Tuschl, K.; Clayton, P.T.; Gospe, S.M.; Gulab, S.; Ibrahim, S.; Singhi, P.; Aulakh, R.; Ribeiro, R.T.; Barsottini, O.G.; Zaki, M.S.; et al. Syndrome of hepatic cirrhosis, dystonia, polycythemia, and hypermanganesemia caused by mutations in SLC30A10, a manganese transporter in man. Am. J. Hum. Genet. 2012, 90, 457-466. [CrossRef]

156. Knight, T.; Urooj Zaidi, A.; Wu, S.; Gadgeel, M.; Buck, S.; Ravindranath, Y. Mild erythrocytosis as a presenting manifestation of PIEZO1 associated erythrocyte volume disorders. Pediatr. Hematol. Oncol. 2019, 36, 317-326. [CrossRef]

157. Filser, M.; Giansily-Blaizot, M.; Grenier, M. Increased incidence of germline PIEZO1 mutations in individuals with idiopathic erythrocytosis. Blood 2021, 137, 1828-1832. [CrossRef]

158. Kiger, L.O.; Guitton, C.; Bendélac, L.; Ghazal, K.; Proulle, V.; Galacteros, F.; Junot, C.; Fenaille, F.; Roméo, P.H.; Garçon, L.; et al. Piezo1-xerocytosis red cell metabolome shows impaired glycolysis and increased hemoglobin oxygen affinity. Laurent. Blood Adv. 2021, 5, 84-88. [CrossRef] [PubMed]

159. Ma, S.; Dubin, A.E.; Zhang, Y.; Mousavi, S.A.R.; Wang, Y.; Coombs, A.M.; Loud, M.; Andolfo, I.; Patapoutian, A. A role of PIEZO1 in iron metabolism in mice and humans. Cell 2021, 184, 969-982. [CrossRef]

160. Jankovsky, N.; Caulier, A.; Demagny, J.; Guitton, C.; Djordjevic, S.; Lebon, D.; Ouled-Haddou, H.; Picard, V.; Garçon, L. Recent advances in the pathophysiology of PIEZO1-relatedhereditary xerocytosis. Am. J. Hematol. 2021, 96, 1017-1026. [CrossRef] [PubMed] 